\title{
Discovery and Structure-Based Optimization of 2-Ureidothiophene-3-Carboxylic Acids as Dual Bacterial RNA Polymerase and Viral Reverse Transcriptase Inhibitors
}

\author{
Walid A. M. Elgaher, ${ }^{\dagger}$ Kamal K. Sharma, ${ }^{\ddagger}$ Jörg Haupenthal,${ }^{\dagger}$ Francesco Saladini,${ }^{\S}$ Manuel \\ Pires, ${ }^{\ddagger}$ Eleonore Real,${ }^{\ddagger}$ Yves Mély, ${ }^{\ddagger}$ and Rolf W. Hartmann $*, \dagger$
}

${ }^{\dagger}$ Helmholtz Institute for Pharmaceutical Research Saarland (HIPS), Department of Drug Design and Optimization \& Saarland University, Pharmaceutical and Medicinal Chemistry, Campus E8.1, 66123 Saarbrücken, Germany

\$ Laboratoire de Biophotonique et Pharmacologie, UMR 7213 CNRS, Université de Strasbourg, Faculté de pharmacie, 74 route du Rhin, 67401 Illkirch, France

${ }^{\S}$ Department of Medical Biotechnologies, University of Siena, Viale Mario Bracci 16, 53100 Siena, Italy

\begin{abstract}
We are concerned with the development of novel anti-infectives with dual antibacterial and antiretroviral activities for MRSA/HIV-1 co-infection. To achieve this goal, we exploited for the first time the mechanistic function similarity between the bacterial RNA polymerase (RNAP) "switch region" and the viral non-nucleoside reverse transcriptase inhibitor (NNRTI) binding site. Starting from our previously discovered RNAP inhibitors, we managed to develop potent RT inhibitors effective against several resistant HIV-1 strains with maintained or enhanced RNAP inhibitory properties following a structure-based design approach. A quantitative structure-activity relationship (QSAR) analysis revealed distinct molecular features necessary for RT inhibition. Furthermore, mode of action (MoA) studies revealed that these compounds inhibit RT non-competitively, through a new mechanism via closing of the RT clamp. In addition, the novel RNAP/RT inhibitors are characterized by a potent antibacterial activity against $S$. aureus and in cellulo antiretroviral activity against NNRTIresistant strains. Using HeLa and HEK 293 cells the compounds showed only marginal cytotoxicity.
\end{abstract}




\section{INTRODUCTION}

Human immunodeficiency virus type 1 (HIV-1) is the causative agent of the acquired immune deficiency syndrome (AIDS), which is one of the major lethal infectious diseases endangering humanity. In 2014, more than 37 million people worldwide were HIV-infected with a mortality of approximately 1.2 million. ${ }^{1}$ The HIV-1 retrovirus targets the CD4 cells resulting in an impairment of the immune system. In consequence, HIV patients are a defenseless prey for bacterial infections e.g. tuberculosis (TB) and methicillin-resistant Staphylococcus aureus (MRSA). ${ }^{2-4}$ MRSA co-infection is characterized by a high incidence rate. ${ }^{5}$ In addition, the emergence of multidrug resistant MRSA markedly increased among HIV patients. ${ }^{6,7}$ Current treatment of HIV infection requires a combination of at least three antiretroviral drugs. This highly active antiretroviral therapy (HAART) permits efficient suppression of virus replication and inhibits disease progression. However, the evolution of antiretroviral drug resistance is still presenting an intractable problem due to the high viral mutation rate and non-compliance to antiretroviral therapy (ART) ${ }^{8-10}$ Although the FDA recently approved a combined ART as one pill daily that could improve patient adherence, ${ }^{11}$ the resistance issue is not yet solved. Treatment of MRSA/HIV-1 co-infection is even more challenging. In addition to the above mentioned issues, administration of antibiotics should take into consideration the ongoing prevalence of resistant bacteria in HIV-1 populations, ${ }^{6,7}$ as well as potential drug interactions between antiretroviral and antibacterial agents. ${ }^{12}$ Hence, there is an urgent need for a one compound therapy of MRSA/HIV-1 co-infections. Combining antibacterial and antiretroviral properties in a single molecule should be beneficial in different aspects: it will improve patient adherence to ART by reduction of medications' regimen, ${ }^{11}$ and consequently decrease the probability of treatment failure. Moreover, prescribing such anti-infective medication will avoid drug interactions, ${ }^{12}$ and lower the costs of care as well. ${ }^{13}$

HIV-1 RT is a key target for ART. It reverse-transcribes the single-stranded viral RNA to doublestranded DNA, which is essential for virus replication. ${ }^{14}$ There are two main classes inhibiting RT: nucleoside RT inhibitors (NRTIs) and NNRTIs. NRTIs are nucleotide analogues that are incorporated into viral DNA leading to chain termination. Through binding to an allosteric binding site, NNRTIs inhibit RT non-competitively. ${ }^{15,16}$ In bacteria, RNAP is an essential enzyme for bacterial viability ${ }^{17}$ 
and has consequently become a pivotal drug target. It is responsible for transcription by converting double-stranded DNA to single-stranded RNA, which is a prerequisite for protein synthesis. Consequently, there is a functional relationship between bacterial RNAP and viral RT. In this context, the clinically used RNAP inhibitor rifampicin does also inhibit viral RT. ${ }^{18}$ On the other side, HIV-1 RT monoclonal antibodies were found to inhibit E. coli RNAP, indicating structural and functional similarities between both enzymes. ${ }^{19}$ Recently, a new RNAP binding site, the "switch region", was discovered with a mechanistic function close to that of the NNRTI binding site. ${ }^{20}$ However, these important insights have not yet been exploited for drug discovery.

In previous works, we developed new classes of RNAP "switch region" inhibitors using different drug design approaches. ${ }^{21,22}$ Their mode of action was confirmed by biophysical methods and mutation studies. ${ }^{23}$ Beside their activity against MRSA, the compounds showed no cross-resistance with rifampicin and a low rate of resistance development in E.coli TolC..$^{22,23}$ Thus, our RNAP inhibitors should be a good starting point for designing such dual acting anti-infectives. For testing our compounds for RT inhibition, we applied our recently developed Förster resonance energy transfer (FRET) based polymerization assay. ${ }^{24}$ Nevirapine (NVP) as an NNRTI and zidovudine (AZT-TP) as an NRTI were used as references. For hit optimization, we employed a structure-based design approach. Indeed, we succeeded in developing the first anti-infectives with dual antibacterial and antiretroviral activities.

\section{RESULTS AND DISCUSSION}

\section{Design of Compounds and SAR}

In order to identify the privileged scaffold for HIV-1 RT inhibition among various classes of switch region binding RNAP inhibitors, we selected eight compounds representing four regioisomeric ureidothiophenes (Chart 1). 
<smiles>[R]c1ccc(-c2cc(NC(=O)N(CC)Cc3ccccc3)c(C(=O)O)s2)cc1</smiles>

Class I

1,2<smiles>[R]c1cccc(-c2csc(NC(=O)N(CC)Cc3ccccc3)c2C(=O)O)c1</smiles>

5,6<smiles>[R]c1ccc(-c2cc(C(=O)O)c(NC(=O)N(CC)Cc3ccccc3)s2)cc1</smiles>

3,4<smiles>[R]c1ccccc1-c1csc(C(=O)O)c1NC(=O)N(CC)Cc1ccccc1</smiles>

Class IV

7, 8

\begin{tabular}{|l|c|}
\hline Compound & $\mathrm{R}$ \\
\hline $\mathbf{1}, \mathbf{3}, \mathbf{5}, \mathbf{7}$ & $4-\mathrm{Cl}$ \\
$\mathbf{2}, \mathbf{4}, \mathbf{6}, \mathbf{8}$ & $3-\mathrm{Cl}, \mathbf{4 - \mathrm { Cl }}$ \\
\hline
\end{tabular}

Chart 1. Structures of the ureidothiophene regioisomers used for finding the privileged scaffold for RT inhibition.

Results revealed that only compound 4 (class II) showed a high RT inhibitory activity $\left(\mathrm{IC}_{50}=0.9 \mu \mathrm{M}\right.$, Table 1). This indicates that the introduction of an additional chlorine substituent in the 3-position of the phenyl ring leads to a dramatic increase in potency (4 vs $\mathbf{3}$ ), which is more pronounced than observed for RNAP inhibition..$^{21,22}$ Comparing class II compounds which are highly similar to compounds of class I (the only difference is the position of the $\mathrm{S}$ in the thiophene ring) and had shown similar RNAP inhibition, ${ }^{22}$ strong differences regarding the inhibition of RT were observed, too. This finding can be attributed to the different binding sites and the slight differences in the molecular properties of the ligands. Comparing the RNAP "switch region" and the RT allosteric binding site, it becomes apparent that both pockets are mainly hydrophobic. The RNAP "switch region" is U-shaped with a cavity volume of $\sim 500 \AA^{3}{ }^{25}$ The RT allosteric binding site is highly flexible regarding size, i.e. it is nonexistent in absence of NNRTIs, ${ }^{26,27}$ whereas it possesses a cavity volume of $620-720 \AA^{3}$ in presence of NNRTIs. ${ }^{14}$ Analyzing the molecular similarity between class I and II in silico by a 4-point pharmacophore fingerprint method ${ }^{28}$ and the Tanimoto coefficient $\left(\mathrm{T}_{\mathrm{C}}\right)$ as a similarity metric, class I 
showed partial similarity to II $\left(\mathrm{T}_{\mathrm{C}}=0.75\right)$. This is in contrast to the results obtained recently using a 3 point pharmacophore as a fingerprint. ${ }^{22}$ As 4 was the only compound showing a strong inhibition against both enzymes, we focused on class II as the most appropriate scaffold for the development of dual RNAP and RT inhibitors.

Table 1. In Vitro Inhibitory Activities of Compounds 1-8 against HIV-1 RT and E. coli RNAP

\begin{tabular}{ccc}
\hline Compound & \% inhibition of HIV-1 RT at $1 \mu \mathrm{M}$ & $\mathrm{IC}_{50}$ E. coli RNAP $(\mu \mathrm{M})$ \\
\hline $\mathbf{1}$ & $12^{a}$ & 75 \\
$\mathbf{2}$ & $24^{a}$ & 22 \\
$\mathbf{3}$ & 12 & 54 \\
$\mathbf{4}$ & $0.9^{b}$ & 21 \\
$\mathbf{5}$ & 12 & $>100$ \\
$\mathbf{6}$ & 12 & 57 \\
$\mathbf{7}$ & $13^{c}$ & $>200$ \\
$\mathbf{8}$ & $4^{c}$ & 100 \\
\hline${ }^{a} \%$ inhibition at $25 \mu \mathrm{M} ;{ }^{b} \mathrm{IC}{ }_{50}$ value $(\mu \mathrm{M}) ;{ }^{c} \%$ inhibition at $10 \mu \mathrm{M}$.
\end{tabular}

In the next step, we varied the substituents at the ureido motif of $\mathbf{4}$ (compounds 9-11, Table 2). While increasing bulkiness and lipophilicity at the ureido motif led to a potent RNAP inhibitory activity (10), ${ }^{21,22}$ the RT inhibitory activities observed for compounds 9-11 were surprising. Exchange of the ethyl substituent by a hydrogen (9) as well as by a sterically demanding benzyl substituent (10) reduced activity drastically. Activity was restored by omitting the methylene spacer of the $\mathrm{R}^{1}$ substituent in 9, i.e. exchanging the benzyl group by a phenyl (11). As compound $\mathbf{1 1}$ shows a better ligand efficiency ${ }^{29}$ and ligand-lipophilicity efficiency ${ }^{29}$ compared to 4 (LE: 0.32 vs 0.29; LLE: 2.51 vs 2.33), the subsequent structure modifications were performed based on this compound. 
Table 2. In Vitro Inhibitory Activities of Compounds 9-20 against HIV-1 RT and E. coli RNAP<smiles>[R]N([R])C(=O)Nc1sc(-c2ccc(Cl)c(Cl)c2)cc1C(=O)O</smiles>

\begin{tabular}{|c|c|c|c|c|}
\hline Compound & $\mathrm{R}^{1}$ & $\mathrm{R}^{2}$ & $\mathrm{IC}_{50} \mathrm{HIV}-1 \mathrm{RT}(\mu \mathrm{M})$ & $\mathrm{IC}_{50} E$. coli $\mathrm{RNAP}(\mu \mathrm{M})$ \\
\hline 4 & & 约 & 0.9 & 21 \\
\hline 9 & & $\mathrm{H}$ & $64^{a}$ & 43 \\
\hline 10 & & & $63^{a}$ & 7 \\
\hline 11 & & $\mathrm{H}$ & 1.2 & 20 \\
\hline 12 & & $\mathrm{H}$ & 0.7 & 14 \\
\hline 13 & & $\mathrm{H}$ & 0.8 & 22 \\
\hline 14 & & $\mathrm{H}$ & $64^{a}$ & 53 \\
\hline 15 & & $\mathrm{H}$ & 0.6 & 27 \\
\hline 16 & & $\mathrm{H}$ & 0.8 & 40 \\
\hline 17 & & $\mathrm{H}$ & 0.3 & 19 \\
\hline 18 & & $\mathrm{H}$ & 0.1 & 26 \\
\hline 19 & & $\mathrm{H}$ & 0.9 & 8 \\
\hline 20 & & $\mathrm{H}$ & 0.6 & 23 \\
\hline NVP & - & - & 0.1 & $>200$ \\
\hline AZT-TP & - & - & 7.0 & n.d. ${ }^{b}$ \\
\hline
\end{tabular}

${ }^{a} \%$ inhibition at $25 \mu \mathrm{M} ;{ }^{b}$ not determined. 
In order to reduce the number of compounds to be synthesized, we followed a structure-based design strategy. Using a high resolution co-crystal of the RT-NVP complex (PDB code 1VRT), ${ }^{14}$ we performed an induced fit molecular docking of $\mathbf{1 1}$ into the RT allosteric binding site. The compound adopted a U-shape stabilized by an intramolecular hydrogen bond between the ureido $\mathrm{NH}$ and the carboxylate group forming a six membered ring (Figure 1). The thiophene core is located lowermost near the cavity entrance, while the 3,4-dichlorophenyl and the N-phenyl moieties are positioned uppermost overlapping the two pyridine rings of NVP. Four hydrophobic interactions characterize the binding of $\mathbf{1 1}$ to the NNRTI binding pocket. Two arene-H interactions can be observed between Leu100 and the thiophene core as well as Leu100 and the 3,4-dichlorophenyl moiety. The latter also binds to Val106 through an arene-H interaction from the other side. The fourth interaction is an edgeto-face (T-shaped) arene interaction between Trp229 and the $m$-position of the N-phenyl group. Binding is further strengthened through a hydrogen bond interaction between Lys101 and the carboxylate $\mathrm{C}=\mathrm{O}$ group.

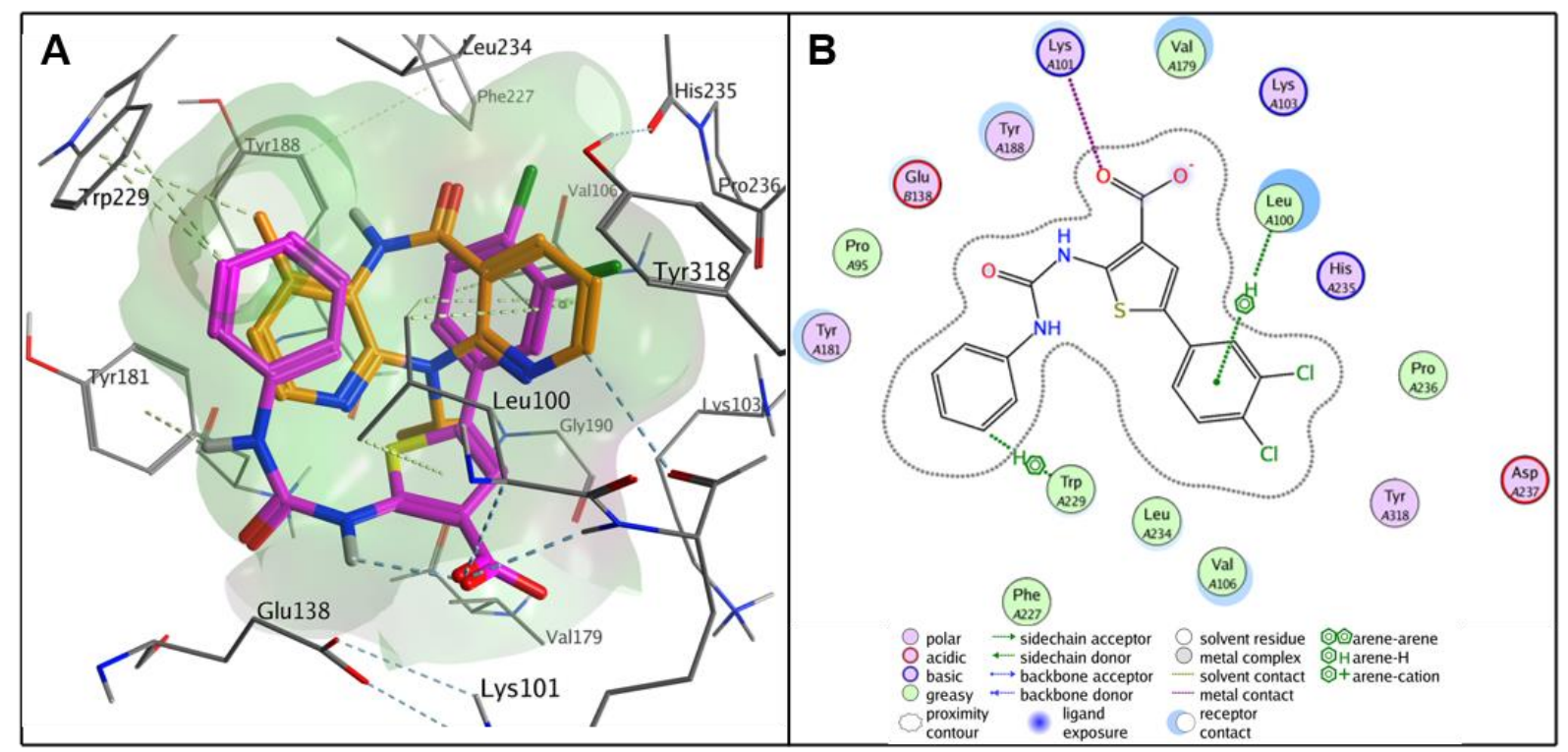

Figure 1. (A) Docking pose of $\mathbf{1 1}$ (magenta) compared to NVP (orange) in the RT allosteric binding site: hydrophobic surface (green), polar surface (pink); (B) 2D ligand interactions of 11. 
According to the docking results, all three aromatic motifs of $\mathbf{1 1}$ are essential for binding. Moreover, no $\pi-\pi$ contacts between $\mathbf{1 1}$ and the frequently mutated amino acids Tyr181 and $\operatorname{Tyr} 188^{10}$ were observed. Interestingly, mutations of the amino acids in contact with $\mathbf{1 1}$ are known to result in high (Trp229, Val106, Leu100) and low fitness costs (Lys101). ${ }^{10,30-32}$

Since Trp229, Phe227 and Leu234 belong to the polymerization-essential "primer grip" and are known to show low mutation frequency, ${ }^{14,32,33}$ we further optimized our compounds for interaction with these highly conserved residues. To achieve this goal, we exploited the space between the $p$ position of the $\mathrm{N}$-phenyl moiety and this conserved region by introduction of diverse substituents with varying bulkiness, electronic and lipophilic properties (12-20, Table 2). Results indicate that except for compound 14, the new modifications improve the activity up to 12-fold (18). The RT inhibitory activity of compound $\mathbf{1 8}$ is comparable to that of NVP and significantly higher than that of AZT-TP. Inspection of the substituent constants and molecular properties of the new compounds (Table S1) reveals that hydrophilic and hydrogen bond donor/acceptor substituents at the N-phenyl group are important for activity. Obviously, activity can be enhanced to a certain extent by increasing the conformational flexibility of the compounds. Interestingly, introduction of aromatic moieties (phenyl or 1,2,4-triazolyl) at the sulfonamide or the acetamide group negatively affects RT inhibitory activity (19 vs 18 , and 16 vs 15) leading to the hypothesis that too bulky substituents at the ureido motif are not favorable for RT inhibition. These findings are in agreement with our docking model (Figure 1), as these aryl motifs elicit a steric clash with the amino acid residues (Tyr188, Phe227, Trp229 and Leu234) lining the deep side of the NNRTI binding pocket. As a consequence of this, they either are shifted in the binding cavity outward or adopt another conformation leading to lower binding interaction.

For further SAR elucidation, we calculated a QSAR model for compounds 11-20 using a multiple regression analysis

$p I C_{50}=4.83+1.15 P C^{+}-0.12 v s a \_d o n-0.27$ SMR

$\left(n=10, R^{2}=0.94, R M S E=0.13\right)$

Where $p I C_{50}$ is $-\log I C_{50}, P C^{+}$is the total positive partial charge, vsa_don is the sum of van der Waals surface areas of pure hydrogen bond donors, and SMR is molecular refractivity. 
Equation 1 reveals a role of electrostatic and steric interactions for activity. Increasing the positive partial charge seems beneficial, whereas the number of hydrogen bond donor atoms at the N-phenyl moiety should be kept to a minimum (0-1 atoms). The inverse correlation with molecular refractivity underlines the importance of less polarizable and non-bulky substituents at the ureido motif for RT inhibition.

Regarding RNAP inhibition, the modifications were tolerated or even enhanced the activity ( $\mathbf{1 2}$ and 19). This could be attributed to the flexibility of this class of compounds and their ability to adopt more than one binding mode within the RNAP "switch region". ${ }^{23}$

Notably, as NVP shows no RNAP inhibitory activity, this stresses that the 2-ureidothiophen-3carboxylic acids present a privileged structure for dual RNAP/RT inhibition. The fact that the new inhibitors show different activity profiles against the two target enzymes, resulting in compound $\mathbf{1 0}$ as the most potent RNAP inhibitor and $\mathbf{1 8}$ as the most active RT inhibitor, indicates specificity of the compounds and excludes promiscuity.

\section{Mode of Action on RT Polymerization}

To characterize the mode of action through which our compounds inhibit RT, we monitored first their effects on the binding parameters and orientation of RT on a model primer/template (p/t) duplex. To this end, we used a FRET assay with RT labeled by Alexa488 and a p/t duplex labeled by carboxytetramethylrhodamine (TAMRA). ${ }^{34}$ The labeled RT mutant was found to bind to the p/t duplex with an affinity of $\sim 3 \mathrm{nM}$ (Figure S1 and Table S2), in good agreement with values reported for DNA $\mathrm{p} / \mathrm{t}$ sequences in the literature (Table S2). ${ }^{35}$ Interestingly, similar affinities as well as no change in RT orientation on the duplex were observed in the presence of compounds 4, 11-13, and 15-20, indicating that these compounds marginally affected the binding of RT to the p/t duplexes, as anticipated for NNRTIs (Table S2).

In a next step, we investigated whether these compounds had the same mode of action as NNRTIs. As shown above, the latter bind usually to the hydrophobic pocket in the palm subdomain of p66 and inhibit RT via an allosteric mechanism, ${ }^{26,27,36}$ forcing the p66 thumb into an open extended position in respect to the finger domain, which prevents deoxyribonucleotides (dNTPs) incorporation ${ }^{37}$ (Figure 
S2C). In order to monitor the effect of our compounds on the relative motions of the thumb and finger domains, we developed a fluorescence-based assay with a RT double mutant where both Lys 287 and Trp24 residues were replaced by cysteine residues.

By labeling the two Cys residues with Bodipy dyes, the intramolecular distance changes associated to the motion of RT's thumb and finger could be monitored by fluorescence spectroscopy. This distance is a key parameter as the relative separation between the thumb and finger subdomains defines the opening and closing of the clamp that holds and positions $\mathrm{p} / \mathrm{t}$ duplexes at the polymerase active site (Figure S2B). A precise positioning of the primer 3 '-end with respect to the polymerase active site (Asp110, Asp185 and Asp186) is required for the catalytic addition of a nucleotide. Due to the close proximity of the finger and thumb in the absence of p/t (Figure S2A), the two Bodipy probes were observed to quench each other, providing a low emission (Figure 2A).
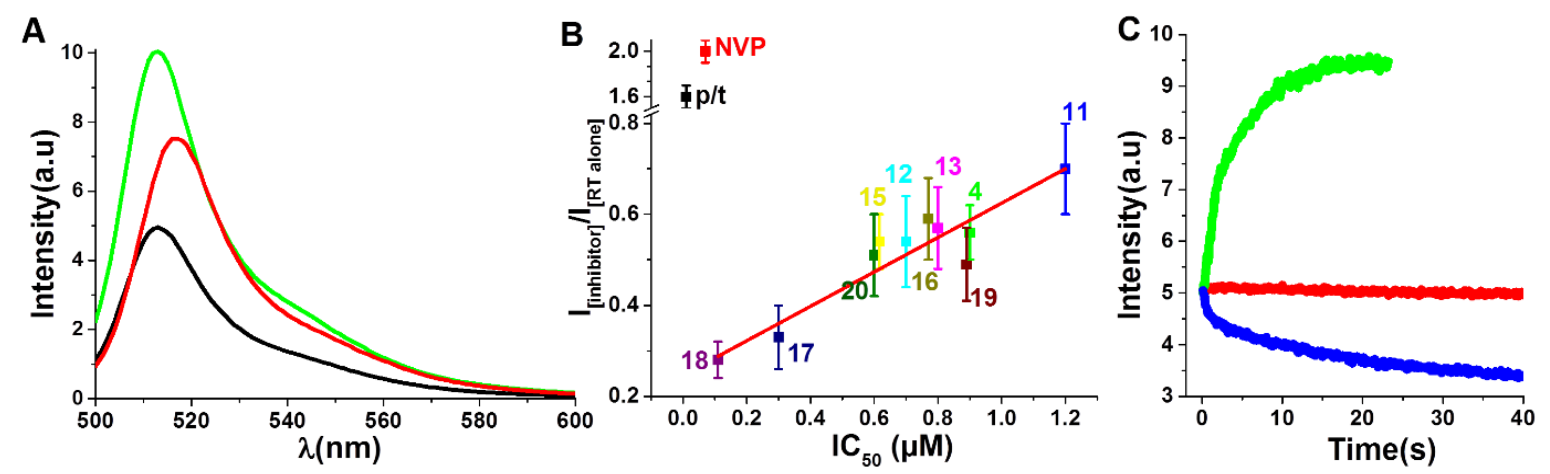

Figure 2. Conformational changes of bodipy-labeled RT p66 W24C+K287C mutant. (A) Emission spectra of $60 \mathrm{nM}$ bodipy-labeled RT in the absence (black line) or in the presence of $160 \mathrm{nM} \mathrm{p} / \mathrm{t}$ duplex (red line) or $10 \mu \mathrm{M} \mathrm{NVP} \mathrm{(green} \mathrm{line);} \mathrm{(B)} \mathrm{Graph} \mathrm{representing} \mathrm{the} \mathrm{ratio} \mathrm{between} \mathrm{the}$ fluorescence intensities of the $100 \mathrm{nM}$ doubly-labeled RT in presence of either the p/t duplex (160 $\mathrm{nM})$ or NVP $(10 \mu \mathrm{M})$ or the tested compounds $(3 \mu \mathrm{M})$ to the fluorescence intensity of the free form. Red line corresponds to the best fit with linear regression $\left(y=m^{*} x+b\right)$, with values of slope $(m)=$ $0.38( \pm 0.04) \mu \mathrm{M}$ and intercept $(b)=0.25( \pm 0.03)$. Excitation wavelength was $490 \mathrm{~nm}$ and ratios were calculated at emission wavelength of $510 \mathrm{~nm}$; (C) Stopped-flow kinetic traces of $60 \mathrm{nM}$ doubly labeled RT in the absence (red trace) and the presence of $10 \mu \mathrm{M}$ NVP (green trace) or compound 11 (blue trace). All traces were fitted by eq 2 and the rate constant values given in Table S2. Excitation wavelength was $490 \mathrm{~nm}$ and emission was collected by using a 525/50 $\mathrm{nm}$ band pass emission filter. 
In contrast, a 1.6-fold increase in Bodipy fluorescence was observed on binding to p/t (Figure 2A and 2B), in line with the expected increase in the distance between the thumb and finger (Figure S2B). An even higher fluorescence increase (two-fold) was observed in the presence of NVP (Fig 2A and 2B), as anticipated from NVP's ability to further separate the two RT subdomains and block them in this open position (Figure S2C). Altogether, the data obtained with the Bodipy-labeled RT were fully consistent with the molecular structures of RT, validating this assay as a convenient means to investigate the inhibitory mechanisms of the synthesized RT inhibitors. In contrast to NVP and p/t duplex, a decrease in Bodipy fluorescence was observed with all tested compounds (Figure 2B). Since no fluorescence quenching was observed when free Bodipy was titrated to the compounds (data not shown), these compounds probably exerted an effect opposite to NVP, decreasing the distance between thumb and finger subdomains. Therefore, the compounds likely exert their inhibitory activity by blocking the RT clamp in a closed conformation.

To get further information on the inhibition mechanism of our compounds, we monitored the changes in fluorescence in real time by stopped-flow (Figure 2C and Table S2). Using NVP as a control, a mono-exponential increase of Bodipy emission was observed (Figure 2C and Table S2), suggesting that the NVP-induced opening of RT clamp occurs in a single step. The kinetic traces were fitted by using

$$
I(t)=I_{F}-\left(I_{F}-I_{0}\right) e^{\left(-k_{o b s}(t-t 0)\right)}
$$

where $t 0$ is the dead time, $k_{o b s}$ is the observed kinetic rate constant and $I_{0}$ and $I_{F}$ are the fluorescence intensities before and after addition of inhibitors, respectively. The $I_{0}$ value was obtained from the steady-state fluorescence spectrum of the doubly labeled mutant and was thus fixed.

Similarly, a mono-exponential decrease in Bodipy emission was observed with all compounds (Figure 2C and Table S2), suggesting that they induce the closing of RT clamp, also in a single step. The kinetic rate constant values of all compounds were found to fluctuate in a narrow range, indicating that they exhibit similar mechanisms of RT inhibition. Interestingly, a clear correlation could be observed between the closing of the clamp and the $\mathrm{IC}_{50}$ values (Figure $2 \mathrm{~B}$ ). This indicates that the inhibitory activity of the compounds is related to their ability to efficiently close the RT clamp and thus, hinder the incorporation of dNTPs. 


\section{Antibacterial and Antiretroviral Activities}

We complemented our in vitro results by firstly evaluating the activity of the new RNAP/RT inhibitors against $S$. aureus. Results revealed a high antibacterial effect for the majority of the compounds with minimum inhibitory concentrations (MICs) between 3-13 $\mu \mathrm{g} / \mathrm{mL}$ (Table 3). Markedly, these values correlate with the corresponding RNAP inhibitory activities. Secondly, we applied a cellular infectivity assay to assess the antiretroviral activity of our compounds. This assay is based on the infection of HeLa cells by a third generation of pseudoviral particles, ${ }^{38}$ mimicking the early steps of the HIV-1 life cycle. Most of the tested compounds exhibited good antiretroviral activities in the low micromolar range (Table 3). Noticeably, a marked difference was observed in the activity profiles when comparing the in vitro and in cellulo results: The compounds turned out to be less active in the cellular system. This might be due to the lipophilic nature of the compounds leading to an inefficient permeation into the cells, or an interaction with other proteins in the antiviral assay leading to a lowered concentration at the target enzyme.

Next, we examined the effect of our compounds on cell viability in two different cell lines (HeLa and HEK 293) and found them to display only marginal or no cytotoxicity (Table 3).

Table 3. Antibacterial, Antiretroviral and Cytotoxic Activities of the Dual RNAP/RT Inhibitors.

\begin{tabular}{ccccc}
\hline Compound & $\begin{array}{c}\text { MIC S. aureus } \\
(\mu \mathrm{g} / \mathrm{mL})\end{array}$ & $\begin{array}{c}\mathrm{IC}_{50} \text { Viral infectivity } \\
(\mu \mathrm{M})\end{array}$ & $\begin{array}{c}\text { \% Inhibition of HeLa cell } \\
\text { viability at } 25 \mu \mathrm{M}\end{array}$ & $\begin{array}{c}\text { LD }_{50} \text { HEK 293 } \\
\text { cells }(\mu \mathrm{M})\end{array}$ \\
\hline $\mathbf{4}$ & 10 & 27 & 23 & 58 \\
$\mathbf{1 1}$ & 6 & 20 & 0 & 61 \\
$\mathbf{1 2}$ & 4 & n.i. $^{a}$ & 0 & 68 \\
$\mathbf{1 3}$ & 8 & 35 & 12 & 80 \\
$\mathbf{1 7}$ & 25 & 30 & 6 & 86 \\
$\mathbf{1 8}$ & 39 & 30 & 0 & $>100$ \\
$\mathbf{1 9}$ & 3 & n.d. $^{b}$ & n.d. & 94 \\
$\mathbf{2 0}$ & 13 & n.d. $^{b}$ & n.d. & $>100$ \\
\hline
\end{tabular}

${ }^{a}$ no inhibition; ${ }^{b}$ not determined.

\section{Antiretroviral Activity in NNRTI Resistant HIV-1 Strains}

Based on the docking study, the binding mode of our new NNRTIs could be advantageous regarding the resistance issue. The numerous interactions between our ligands and the NNRTI binding pocket, especially those with the highly conserved amino acids, should only be moderately affected by the 
single site mutations that result from using other NNRTIs and are responsible for resistance. ${ }^{9,10,30}$ To verify this point and to get more insight into the binding mode of our compounds, we tested the antiviral activity of compounds 11, 18 and 19 against the HIV-1 wild-type (WT) NL4-3 and a panel of strains with multiple resistance mutations to clinically used NNRTIs in a TZM-bl cell line based phenotypic assay (Table 4).

Table 4. Antiretroviral Activity of 11, 18, 19 and Reference NNRTIs against HIV-1 WT (114) and NNRTIs-Resistant Strains (12237, 12235, 12231, 12229).

\begin{tabular}{|c|c|c|c|c|c|}
\hline \multirow[b]{2}{*}{ Compound } & \multirow{2}{*}{$\begin{array}{c}\mathrm{IC}_{50}(\mu \mathrm{M}) \\
114^{d} \\
\text { NL4-3 (WT) }\end{array}$} & \multicolumn{4}{|c|}{ Fold change in susceptibility ${ }^{a}\left(\right.$ biological $^{b}$ or clinical $^{c}$ cut-off) } \\
\hline & & $\begin{array}{c}12237^{d} \\
(\mathrm{~V} 106 \mathrm{I}, \mathrm{Y} 181 \mathrm{C} \\
\mathrm{G} 190 \mathrm{~A}, \mathrm{H} 221 \mathrm{Y})^{e}\end{array}$ & $\begin{array}{c}12235^{d} \\
(\mathrm{~A} 98 \mathrm{G}, \mathrm{K} 101 \mathrm{E} \\
\mathrm{Y} 181 \mathrm{C}, \mathrm{G} 190 \mathrm{~A})^{e}\end{array}$ & $\begin{array}{c}12231^{d} \\
(\mathrm{~K} 103 \mathrm{~N}, \mathrm{~V} 179 \mathrm{~F} \\
\mathrm{Y} 181 \mathrm{C})^{e}\end{array}$ & $\begin{array}{c}12229^{d} \\
(\mathrm{~L} 100 \mathrm{I}, \mathrm{K} 103 \mathrm{~N}, \\
\mathrm{H} 221 \mathrm{Y})^{e}\end{array}$ \\
\hline 11 & 5 & 1 & 3 & $>4$ & $>4$ \\
\hline 18 & 5 & 1.5 & 3.5 & $>4$ & $>4$ \\
\hline 19 & 15 & $>1.5$ & 1 & $>1.5$ & $>1.5$ \\
\hline NVP & $0.1^{f}$ & $>200(4.5)^{b}$ & $>200(4.5)^{b}$ & $>200(4.5)^{b}$ & $>200(4.5)^{b}$ \\
\hline $\mathrm{EFV}$ & $0.002^{f}$ & $26(3)^{b}$ & $>200(3)^{b}$ & $90(3)^{b}$ & $>200(3)^{b}$ \\
\hline ETR & $0.005^{f}$ & $6.0(2.9)^{c}$ & $15(2.9)^{c}$ & $8.8(2.9)^{c}$ & $6.8(2.9)^{c}$ \\
\hline RPV & $0.0009^{f}$ & $3.5(2)^{b}$ & $22(2)^{b}$ & $2.3(2)^{b}$ & $6.3(2)^{b}$ \\
\hline
\end{tabular}

${ }^{\bar{a}}$ Resistant virus $\mathrm{IC}_{50} / \mathrm{WT}$ virus $\mathrm{IC}_{50}$ ratio calculated with the Phenosense assay; ${ }^{b}$ The biological cut-off was determined by in vitro analysis of multiple viral variants not exposed to the drug and defined as the mean fold-change plus two standard deviations with respect to the reference viral strain. It is used when a clinical cut-off has not been established; ${ }^{c}$ The clinical cut-off was determined by statistical analysis of clinical data and is defined as the fold-change value corresponding to loss of drug activity in vivo; ${ }^{d} \mathrm{ID}$ of viruses are referred to the NIH AIDS Reagent Program catalogue number; ${ }^{e}$ The NNRTIs resistance mutations; ${ }^{f} \mathrm{IC}_{50}$ values against WT were previously determined ${ }^{39} ; \mathrm{EFV}=$ efavirenz, $\mathrm{ETR}=$ etravirine, $\mathrm{RPV}=$ rilpivirine.

Our results reveal that the tested compounds show good activity against the WT $\left(\mathrm{IC}_{50 \mathrm{~S}} 5-15 \mu \mathrm{M}\right)$ as well as against the mutants 12237 and 12235 . In contrast, they are unable to halt the replication of 12231 and 12229 strains. At the same time, the reference drugs NVP, EFV and ETR show a dramatic loss of potency against all resistant mutants.

These data indicate that our compounds are still able to bind to and to inhibit the RTs with mutations K101E, V106I, Y181C and G190A, which confer high-level resistance against NNRTIs. ${ }^{10,30}$ This can on the one side be attributed to the presence of essential contacts between our ligands and the amino 
acid residues of high fitness costs such as Leu100, Phe227, and Trp229. On the other side, due to the conformational flexibility of our compounds they can easily adopt to the steric changes in the binding site of the mutated proteins. Interestingly, the K103N mutation seems to have a negative effect on our compounds' RT inhibition and antiretroviral activity. This result does not contradict our predicted binding mode, since this mutation affects the pocket entrance. ${ }^{40}$ In addition, the L100I mutation may impair the binding to RT.

These findings are consistent with the predicted binding mode of our new NNRTIs and thus further confirm their binding site. Moreover, the fact that no cross-resistance was observed in some NNRTIsresistant strains is an important advantage over the $1^{\text {st }}\left(\mathrm{NVP}\right.$ and EFV) and $2^{\text {nd }}$ generation (ETR and RPV) NNRTIs.

Finally, we performed a docking study for the most active compound $\mathbf{1 8}$ (Figure 3). Comparing to the binding of 11, the eastern part of the molecules binds identically to the protein. Unexpectedly, in the western part a slight change was observed as the newly introduced methanesulfonamido group leads to $\mathrm{CH}-\pi$ interaction with the highly conserved Trp229. As a consequence of this, the N-phenyl ring is slightly shifted downward away from Trp229. Moreover, an atypical hydrogen bond was identified between the conserved Phe227 (as donor) and the 3,4-dichlorophenyl motif (as acceptor). Furthermore, no $\pi-\pi$ interaction was observed between Tyr181 and the N-phenyl moiety (centroidcentroid distance $>4 \AA$ ).

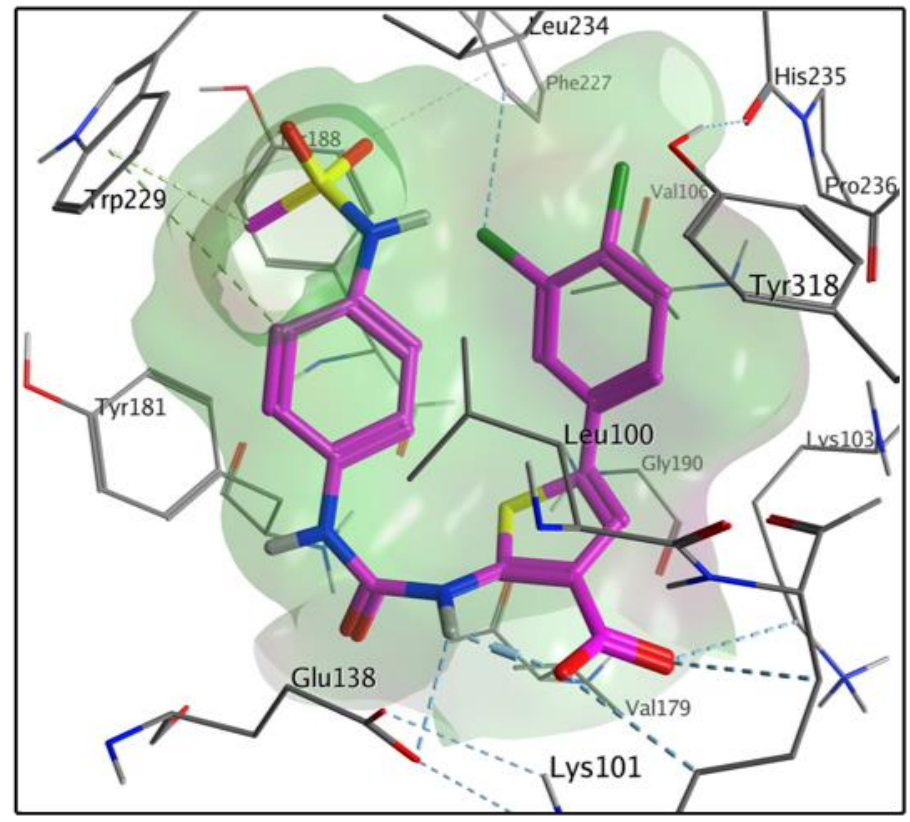

Figure 3. Docking pose of $\mathbf{1 8}$ in the NNRTI binding site. 


\section{Chemistry}

Synthesis of the 5-aryl-2-ureidothiophene-3-carboxylic acids was accomplished through a straightforward procedure starting with 3,4-dichlorophenylacetic acid 21 (Scheme 1). Reduction with $\mathrm{LiAlH}_{4}$ followed by mild oxidation of the produced alcohol 22 using PCC delivered the arylacetaldehyde $\mathbf{2 3}$ in a good yield. Gewald reaction of $\mathbf{2 3}$ with ethyl cyanoacetate and elemental sulfur under basic conditions in a one-pot reaction afforded the 2 -aminothiophene-3-carboxylate $\mathbf{2 4} .^{22}$ The ester was saponified to the corresponding acid $\mathbf{2 5}$, which was treated with BTC to produce the 6arylthiaisatoic anhydride 26. Synthesis was finalized via coupling of $\mathbf{2 6}$ and the appropriate amine in water/TEA $(2: 1)$ mixture at room temperature followed by acidic workup to yield the 5-aryl-2ureidothiophene-3-carboxylic acids 9-20.

Scheme 1. Synthesis of the 2-ureidothiophene-3-carboxylic acids 9-20 ${ }^{a}$<smiles>O=C(O)Cc1ccc(Cl)c(Cl)c1</smiles>

21<smiles>OCCc1ccc(Cl)c(Cl)c1</smiles>

22<smiles>CC(C)C</smiles>

23<smiles>CCOC(=O)c1cc(-c2ccc(Cl)c(Cl)c2)sc1N</smiles>

24<smiles>Nc1sc(-c2ccc(Cl)c(Cl)c2)cc1C(=O)O</smiles>

25<smiles>[R2]NC(=O)Nc1sc(-c2ccc(Cl)c(Cl)c2)cc1C(=O)O</smiles>

26 9-20

${ }^{a}$ Reagents and conditions: (a) $\mathrm{LiAlH}_{4}$, THF, reflux, $2 \mathrm{~h}$; (b) PCC, DCM, rt, $2 \mathrm{~h}$; (c) 1/8 $\mathrm{S}_{8}$, $\mathrm{NCCH}_{2} \mathrm{COOEt}$, TEA, ethanol, reflux, 12 h; (d) KOH, MeOH/ $\mathrm{H}_{2} \mathrm{O}$, reflux, 4 h; (e) BTC, THF, rt, 2 h; (f) $\mathrm{R}^{1} \mathrm{R}^{2} \mathrm{NH}, \mathrm{H}_{2} \mathrm{O} / \mathrm{TEA}, \mathrm{rt}, 2 \mathrm{~h}$.

The $N$-monosubstituted-p-phenylenediamines were prepared from $p$-nitroaniline $\mathbf{2 7}$ keeping the nitro moiety as a hidden protected amino group (Scheme 2). Reaction of 27 with acyl chlorides or sulfonyl chlorides in the presence of pyridine yielded the corresponding amides or sulfonamides, respectively. The nitro derivatives were reduced by iron/ammonium chloride mixture to afford the corresponding amines in excellent yields. 
Scheme 2. Synthesis of the intermediate aromatic amines ${ }^{a}$

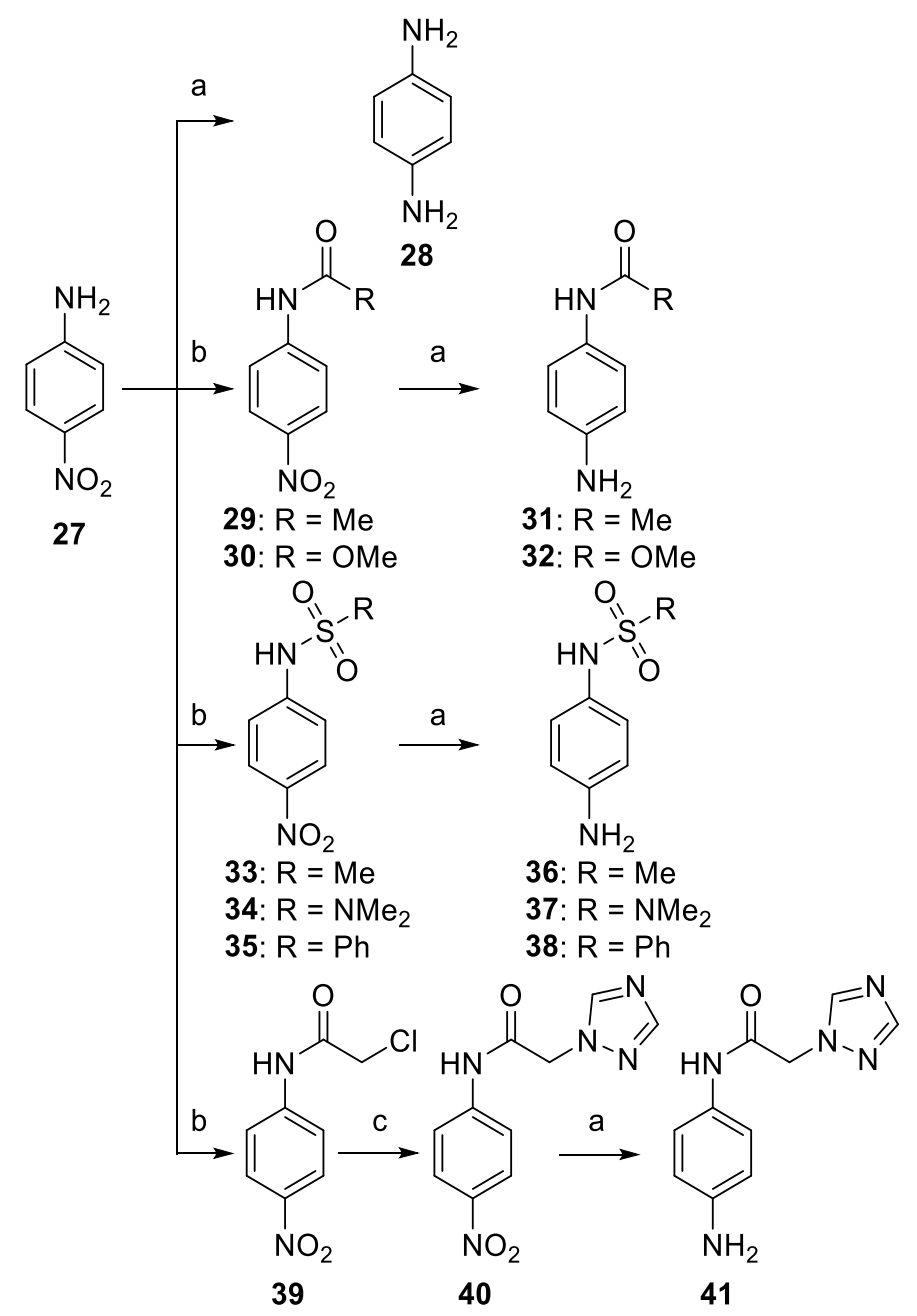

${ }^{a}$ Reagents and conditions: (a) $\mathrm{Fe} / \mathrm{NH}_{4} \mathrm{Cl}$, EtOH, reflux, $1 \mathrm{~h}$; (b) $\mathrm{RCOCl}$ or $\mathrm{RSO}_{2} \mathrm{Cl}$, pyridine/DCM, rt, $12 \mathrm{~h}$; (c) 1,2,4-triazole, $\mathrm{K}_{2} \mathrm{CO}_{3} / \mathrm{DMF}, 70{ }^{\circ} \mathrm{C}, 1 \mathrm{~h}$.

It is noteworthy that TEA is crucial for formation of the desired ureidothiophene carboxylic acids. Modification of the previous procedures that did not employ TEA in the coupling step ${ }^{21,22}$ was necessary to enhance the reaction regioselectivity. Since the utilized anilines in this work are weak nucleophiles, the coupling reaction using $p$-anisidine for example in absence of TEA afforded a mixture of the amide $\mathbf{4 2}$ and the ureidocarboxylic acid $\mathbf{1 3}$ in nearly 1:1 ratio as indicated from the ${ }^{1} \mathrm{H}$ NMR spectrum (Figure S3). In contrast, running the same reaction in presence of TEA produced exclusively the ureidothiophene carboxylic acid $\mathbf{1 3}$ in $100 \%$ regioselectivity (Scheme 3). Moreover, we found that the loss of amine regioselectivity and reactivity is directly proportional to the electron deficiency of the substituted aniline, i.e. no ureidothiophene product could be obtained from the reaction of $\mathbf{2 6}$ with $p$-nitroaniline $\mathbf{2 7}$ even when TEA was applied. 
Scheme 3. Reaction of $\mathbf{2 6}$ with $p$-anisidine in presence and absence of TEA.

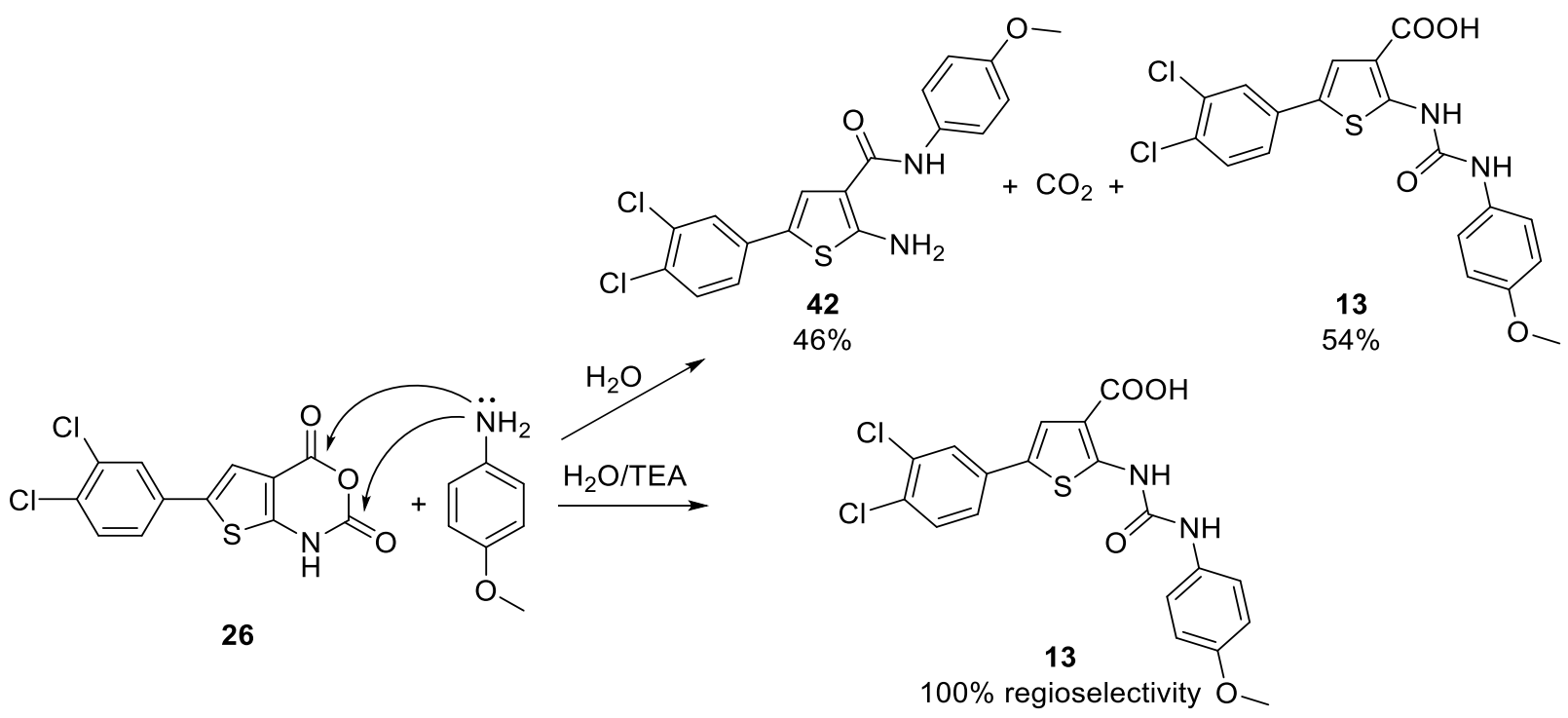

\section{CONCLUSION}

In this work we discovered and developed 2-ureidothiophene-3-carboxylic acids as dual bacterial RNAP and HIV-1 RT inhibitors for the treatment of MRSA/HIV-1 co-infections. This development was based on an unprecedented exploitation of the functional and structural similarities between the RNAP "switch region" and the NNRTI allosteric binding site. First, we identified the privileged structure for RT inhibition by screening four regioisomeric classes of "switch region" binding RNAP inhibitors. Next, we explored the steric volume allowed in the NNRTI binding pocket through enlarging the bulkiness of the ureido moiety. Finally, we applied a structure-based design strategy for hit optimization. We were able to improve the RT inhibitory activity, in parallel with enhancing, or at least maintaining, the activity against RNAP. SAR studies revealed the importance of hydrophilic nonbulky substituents at the ureido side chain for RT inhibition. A MoA investigation revealed a noncompetitive inhibition mechanism of our compounds, which is typical for NNRTIs. Interestingly, the compounds seem to act through a new mechanism via closing of the RT clamp. The new RNAP/RT inhibitors displayed high potency against $S$. aureus as well as in cellulo antiretroviral activity accompanied by marginal or no cytotoxicity. Furthermore, these compounds were active against NNRTI-resistant strains. Thus, our work establishes the basis for the development of a single compound therapy not only against MRSA/HIV co-infection, but also against other challenging coinfections of major public health concern especially Mtb/HIV coinfection. 


\section{EXPERIMENTAL SECTION}

\section{Materials and Methods}

Starting materials and solvents were purchased from commercial suppliers, and used without further purification. All chemical yields refer to purified compounds, and were not optimized. Reaction progress was monitored using TLC Silica gel $60 \mathrm{~F}_{254}$ aluminium sheets, and visualization was accomplished by UV at $254 \mathrm{~nm}$. Flash chromatography was performed using silica gel $60 \AA$ (40-63 $\mu \mathrm{m})$. Preparative RP-HPLC was carried out on a Waters Corporation setup contains a 2767 sample manager, a 2545 binary gradient module, a 2998 PDA detector and a 3100 electron spray mass spectrometer. Purification was performed using a Waters XBridge column $(\mathrm{C} 18,150 \times 19 \mathrm{~mm}, 5 \mu \mathrm{m})$, a binary solvent system $\mathrm{A}$ and $\mathrm{B}(\mathrm{A}=$ water with $0.1 \%$ formic acid; $\mathrm{B}=\mathrm{MeCN}$ with $0.1 \%$ formic acid) as eluent, a flow rate of $20 \mathrm{~mL} / \mathrm{min}$ and a gradient of $60 \%$ to $95 \%$ B in 8 min were applied. NMR spectra were recorded either on Bruker DRX-500 $\left({ }^{1} \mathrm{H}, 500 \mathrm{MHz} ;{ }^{13} \mathrm{C}, 126 \mathrm{MHz}\right)$, or Bruker Fourier $300\left({ }^{1} \mathrm{H}, 300 \mathrm{MHz} ;{ }^{13} \mathrm{C}, 75 \mathrm{MHz}\right)$ spectrometer at $300 \mathrm{~K}$. Chemical shifts were recorded as $\delta$ values in ppm units by reference to the hydrogenated residues of deuterated solvent as internal standard $\left(\mathrm{CDCl}_{3}\right.$ : $\delta=7.27,77.00$; DMSO-d 6 : $\delta=2.50,39.51)$. Splitting patterns describe apparent multiplicities and are designated as s (singlet), br s (broad singlet), d (doublet), dd (doublet of doublet), t (triplet), q (quartet), m (multiplet). Coupling constants $(J)$ are given in Hertz (Hz). Weak or coalesced signals were elucidated by Heteronuclear Multiple Quantum Coherence (HMQC) and Heteronuclear Multiple Bond Coherence (HMBC) 2D-NMR techniques. Purity of all compounds used in biological assays was $\geq 95 \%$ as measured by LC/MS Finnigan Surveyor MSQ Plus (Thermo Fisher Scientific, Dreieich, Germany). The system consists of LC pump, autosampler, PDA detector, and single-quadrupole MS detector, as well as the standard software Xcalibur for operation. RP C18 Nucleodur 100-5 $(125 \times 3$ mm) column (Macherey-Nagel GmbH, Dühren, Germany) was used as stationary phase, and a binary solvent system $\mathrm{A}$ and $\mathrm{B}(\mathrm{A}=$ water with $0.1 \% \mathrm{TFA}$; $\mathrm{B}=\mathrm{MeCN}$ with $0.1 \% \mathrm{TFA}$ ) was used as mobile phase. In a gradient run the percentage of B was increased from an initial concentration of $0 \%$ at 0 min to $100 \%$ at $15 \mathrm{~min}$ and kept at $100 \%$ for $5 \mathrm{~min}$. The injection volume was $10 \mu \mathrm{L}$ and the flow rate was set to $800 \mu \mathrm{L} / \mathrm{min}$. MS (ESI) analysis was carried out at a spray voltage of $3800 \mathrm{~V}$, a capillary 
temperature of $350{ }^{\circ} \mathrm{C}$ and a source CID of $10 \mathrm{~V}$. Spectra were acquired in positive mode from 100 to $1000 \mathrm{~m} / \mathrm{z}$ and at $254 \mathrm{~nm}$ for UV tracing.

General procedure for synthesis of 5-(3,4-dichlorophenyl)-2-[3-(4(un)substitutedphenyl)ureido]thiophene-3-carboxylic acids 11-20

To a stirred suspension of the thiaisatoic anhydride $\mathbf{2 6}(150 \mathrm{mg}, 0.48 \mathrm{mmol})$ in a mixture of water (6 $\mathrm{mL})$ and TEA $(1 \mathrm{~mL})$, the appropriate amine $(1.0 \mathrm{mmol})$ in TEA $(2 \mathrm{~mL})$ was added. The reaction mixture was stirred at $\mathrm{rt}$ overnight, then poured on ice-cooled $2 \mathrm{~N} \mathrm{HCl}(40 \mathrm{~mL})$, and extracted with EtOAc/THF (1:1, $40 \mathrm{~mL})$. The organic layer was washed with cold $2 \mathrm{~N} \mathrm{HCl} /$ brine $(1: 1,2 \times 40 \mathrm{~mL})$, dried over anhydrous $\mathrm{MgSO}_{4}$, and concentrated in vacuo. The obtained crude material was suspended in $n$-hexane/EtOAc $(4: 1,50 \mathrm{~mL})$, stirred in a water bath at $40{ }^{\circ} \mathrm{C}$ for $10 \mathrm{~min}$, cooled, and collected by filtration.

\section{5-(3,4-Dichlorophenyl)-2-(3-phenylureido)thiophene-3-carboxylic acid (11)}

Yield 90\%; beige solid; ${ }^{1} \mathrm{H}$ NMR (500 MHz, DMSO-d 6 ) $\delta 13.02$ (br s, 1H), 10.61 (br s, 1H), 10.36 (br s, $1 \mathrm{H}), 7.88(\mathrm{~d}, J=2.0 \mathrm{~Hz}, 1 \mathrm{H}), 7.63(\mathrm{~s}, 1 \mathrm{H}), 7.60(\mathrm{~d}, J=8.0 \mathrm{~Hz}, 1 \mathrm{H}), 7.58(\mathrm{dd}, J=8.0,2.0 \mathrm{~Hz}, 1 \mathrm{H})$, $7.52(\mathrm{~m}, 2 \mathrm{H}), 7.33(\mathrm{~m}, 2 \mathrm{H}), 7.04(\mathrm{~m}, 1 \mathrm{H}) ;{ }^{13} \mathrm{C} \mathrm{NMR}\left(126 \mathrm{MHz}, \mathrm{DMSO}-\mathrm{d}_{6}\right) \delta 165.80,150.98,150.15$, $138.86,134.31,131.87,131.07,129.07,128.94$ (2C), 127.72, 126.10, 124.70, 122.77, 122.27, 118.49 (2C), 112.36; m/z (ESI+) $407[\mathrm{M}+\mathrm{H}]^{+} ; \mathrm{t}_{\mathrm{R}}=14.49 \mathrm{~min}$.

\section{5-(3,4-Dichlorophenyl)-2-(3-(4-fluorophenyl)ureido)thiophene-3-carboxylic acid (12)}

Yield 82\%; grey solid; ${ }^{1} \mathrm{H}$ NMR (300 MHz, DMSO-d 6 ) $\delta 13.04$ (br s, $1 \mathrm{H}$ ), 10.60 (br s, 1H), 10.39 (br $\mathrm{s}, 1 \mathrm{H}), 7.88(\mathrm{~d}, J=1.5 \mathrm{~Hz}, 1 \mathrm{H}), 7.63(\mathrm{~s}, 1 \mathrm{H}), 7.59(\mathrm{~m}, 2 \mathrm{H}), 7.51(\mathrm{~m}, 2 \mathrm{H}), 7.17(\mathrm{~m}, 2 \mathrm{H}) ;{ }^{13} \mathrm{C}$ NMR $(75$ MHz, DMSO-d $\left.{ }_{6}\right) \delta 165.81,157.84(\mathrm{~d}, J=239.2 \mathrm{~Hz}, 1 \mathrm{C}), 151.00,150.12,135.17(\mathrm{~d}, J=2.2 \mathrm{~Hz}, 1 \mathrm{C})$, 134.28, 131.86, 131.07, 129.08, 127.75, 126.10, 124.70, 122.25, 120.27 (d, $J=7.5 \mathrm{~Hz}, 2 \mathrm{C}), 115.50$ (d, $J=22.4 \mathrm{~Hz}, 2 \mathrm{C}), 112.37 ; \mathrm{m} / \mathrm{z}(\mathrm{ESI}+) 424[\mathrm{M}]^{+} ; \mathrm{t}_{\mathrm{R}}=14.96 \mathrm{~min}$.

\section{5-(3,4-Dichlorophenyl)-2-(3-(4-methoxyphenyl)ureido)thiophene-3-carboxylic acid (13)}

Yield 86\%; beige solid; ${ }^{1} \mathrm{H}$ NMR (300 MHz, DMSO-d 6 ) $\delta 12.66$ (br s, 1H), 10.56 (br s, 1H), 10.16 (br s, $1 \mathrm{H}), 7.88(\mathrm{~d}, J=1.0 \mathrm{~Hz}, 1 \mathrm{H}), 7.62(\mathrm{~s}, 1 \mathrm{H}), 7.57(\mathrm{~m}, 2 \mathrm{H}), 7.41(\mathrm{~d}, J=8.8 \mathrm{~Hz}, 2 \mathrm{H}), 6.91(\mathrm{~d}, J=8.8$ $\mathrm{Hz}, 2 \mathrm{H}), 3.73(\mathrm{~s}, 3 \mathrm{H}) ;{ }^{13} \mathrm{C}$ NMR (75 MHz, DMSO-d 6 ) $\delta 165.86,155.11,151.04,150.40,134.37$, 
131.86, 131.78, 131.08, 129.01, 127.52, 126.07, 124.69, 122.27, 120.31 (2C), 114.15 (2C), 112.16, $55.20 ; \mathrm{m} / \mathrm{z}(\mathrm{ESI}+) 437[\mathrm{M}+\mathrm{H}]^{+} ; \mathrm{t}_{\mathrm{R}}=14.36 \mathrm{~min}$.

\section{2-(3-(4-Aminophenyl)ureido)-5-(3,4-dichlorophenyl)thiophene-3-carboxylic acid (14)}

Yield 80\%; pink solid; ${ }^{1} \mathrm{H}$ NMR (300 MHz, DMSO-d 6 ) $\delta 11.88$ (br s, 1H), 10.72 (br s, $1 \mathrm{H}$ ), 9.83 (br s, 1H), $7.84(\mathrm{~d}, J=1.0 \mathrm{~Hz}, 1 \mathrm{H}), 7.57(\mathrm{~m}, 3 \mathrm{H}), 7.14(\mathrm{~d}, J=8.6 \mathrm{~Hz}, 2 \mathrm{H}), 6.54(\mathrm{~d}, J=8.6 \mathrm{~Hz}, 2 \mathrm{H}), 3.43(\mathrm{br}$ $\mathrm{s}, 2 \mathrm{H}) ;{ }^{13} \mathrm{C}$ NMR $\left(75 \mathrm{MHz}, \mathrm{DMSO}-\mathrm{d}_{6}\right) \delta 166.19,151.23,150.33,144.86,134.61,131.81,131.06$, $128.75,127.51,126.94,125.90,124.55,122.55,120.92(2 \mathrm{C}), 114.12(2 \mathrm{C}), 112.83 ; \mathrm{m} / \mathrm{z}$ (ESI+) 421 $[\mathrm{M}]^{+} ; \mathrm{t}_{\mathrm{R}}=9.78 \mathrm{~min}$.

\section{2-(3-(4-Acetamidophenyl)ureido)-5-(3,4-dichlorophenyl)thiophene-3-carboxylic acid (15)}

Yield 90\%; beige solid; ${ }^{1} \mathrm{H}$ NMR (500 MHz, DMSO-d 6 ) $\delta 13.04$ (br s, 1H), 10.58 (br s, 1H), 10.27 (br s, 1H), 9.87 (br s, 1H), $7.89(\mathrm{~d}, J=1.9 \mathrm{~Hz}, 1 \mathrm{H}), 7.63(\mathrm{~s}, 1 \mathrm{H}), 7.61(\mathrm{~d}, J=8.5 \mathrm{~Hz}, 1 \mathrm{H}), 7.58(\mathrm{dd}, J=$ 8.5, $1.9 \mathrm{~Hz}, 1 \mathrm{H}), 7.53(\mathrm{~d}, J=9.1 \mathrm{~Hz}, 2 \mathrm{H}), 7.42(\mathrm{~d}, J=9.1 \mathrm{~Hz}, 2 \mathrm{H}), 2.02(\mathrm{~s}, 3 \mathrm{H}) ;{ }^{13} \mathrm{C} \mathrm{NMR}(126 \mathrm{MHz}$, DMSO-d $\left._{6}\right) \delta 167.91,165.79,150.94,150.27,134.60,134.34,133.93,131.85,131.07,129.02,127.60$, $126.09,124.70,122.26,119.62(2 \mathrm{C}), 118.95(2 \mathrm{C}), 112.20,23.87 ; \mathrm{m} / \mathrm{z}(\mathrm{ESI}+) 464[\mathrm{M}+\mathrm{H}]^{+} ; \mathrm{t}_{\mathrm{R}}=17.40$ $\min$.

2-(3-(4-(2-(1H-1,2,4-Triazol-1-yl)acetamido)phenyl)ureido)-5-(3,4-dichlorophenyl)thiophene-3carboxylic acid (16)

Yield 65\%; pale grey solid; ${ }^{1} \mathrm{H}$ NMR (500 MHz, DMSO-d ${ }_{6}$ ) $\delta 13.02$ (br s, $\left.1 \mathrm{H}\right), 10.94$ (br s, $\left.1 \mathrm{H}\right), 10.61$ (br s, 1H), 10.52 (br s, 1H), $8.65(\mathrm{~s}, 1 \mathrm{H}), 8.04(\mathrm{~s}, 1 \mathrm{H}), 7.89(\mathrm{~d}, J=1.9 \mathrm{~Hz}, 1 \mathrm{H}), 7.63(\mathrm{~s}, 1 \mathrm{H}), 7.61(\mathrm{~d}, J$ $=8.5 \mathrm{~Hz}, 1 \mathrm{H}), 7.60(\mathrm{~d}, J=9.1 \mathrm{~Hz}, 2 \mathrm{H}), 7.58(\mathrm{dd}, J=8.5,1.9 \mathrm{~Hz}, 1 \mathrm{H}), 7.47(\mathrm{~d}, J=9.1 \mathrm{~Hz}, 2 \mathrm{H}), 5.21$

$(\mathrm{s}, 2 \mathrm{H}) ;{ }^{13} \mathrm{C}$ NMR $\left(126 \mathrm{MHz}, \mathrm{DMSO}-\mathrm{d}_{6}\right) \delta 165.66,164.11,150.99,150.91,150.13,145.44,134.60$, $134.35,133.78,131.84,131.09,129.00,127.60,126.08,124.72,122.30,119.83(2 \mathrm{C}), 118.94(2 \mathrm{C})$, $112.35,51.82 ; \mathrm{m} / \mathrm{z}(\mathrm{ESI}+) 531[\mathrm{M}+\mathrm{H}]^{+} ; \mathrm{t}_{\mathrm{R}}=17.10 \mathrm{~min}$.

5-(3,4-Dichlorophenyl)-2-(3-(4-((methoxycarbonyl)amino)phenyl)ureido)thiophene-3-carboxylic acid (17)

Yield 65\%; white solid; ${ }^{1} \mathrm{H}$ NMR (500 MHz, DMSO-d 6 ) $\delta 13.01$ (br s, 1H), 10.60 (br s, 1H), 10.25 (br s, 1H), $9.55(\mathrm{br} \mathrm{s}, 1 \mathrm{H}), 7.87(\mathrm{~d}, J=1.9 \mathrm{~Hz}, 1 \mathrm{H}), 7.62(\mathrm{~s}, 1 \mathrm{H}), 7.60(\mathrm{~d}, J=8.2 \mathrm{~Hz}, 1 \mathrm{H}), 7.57(\mathrm{dd}, J=$ 8.2, $1.9 \mathrm{~Hz}, 1 \mathrm{H}), 7.42(\mathrm{~d}, J=8.5 \mathrm{~Hz}, 2 \mathrm{H}), 7.40(\mathrm{~d}, J=8.5 \mathrm{~Hz}, 2 \mathrm{H}), 3.65(\mathrm{~s}, 3 \mathrm{H}) ;{ }^{13} \mathrm{C} \mathrm{NMR}(126 \mathrm{MHz}$, 
DMSO-d $\left._{6}\right) \delta 165.87,154.09,151.01,150.28,134.39,134.36,133.59,131.89,131.11,129.05,127.60$, $126.10,124.72,122.31,119.23(2 \mathrm{C}), 118.91(2 \mathrm{C}), 112.34,51.57 ; \mathrm{m} / \mathrm{z}(\mathrm{ESI}+) 480[\mathrm{M}+\mathrm{H}]^{+} ; \mathrm{t}_{\mathrm{R}}=13.46$ $\min$.

5-(3,4-Dichlorophenyl)-2-(3-(4-(methylsulfonamido)phenyl)ureido)thiophene-3-carboxylic acid (18)

Yield 70\%; white crystals; ${ }^{1} \mathrm{H}$ NMR (300 MHz, DMSO-d 6 ) $\delta 13.01$ (br s, $1 \mathrm{H}$ ), 10.60 (br s, $1 \mathrm{H}$ ), 10.35 (br s, 1H), $9.54($ br s, 1H), $7.88(\mathrm{~d}, J=1.0 \mathrm{~Hz}, 1 \mathrm{H}), 7.62(\mathrm{~s}, 1 \mathrm{H}), 7.58(\mathrm{~d}, J=8.0 \mathrm{~Hz}, 1 \mathrm{H}), 7.56(\mathrm{dd}, J=$ 8.0, $1.0 \mathrm{~Hz}, 1 \mathrm{H}), 7.48(\mathrm{~d}, J=8.6 \mathrm{~Hz}, 2 \mathrm{H}), 7.19(\mathrm{~d}, J=8.6 \mathrm{~Hz}, 2 \mathrm{H}), 2.94(\mathrm{~s}, 3 \mathrm{H}) ;{ }^{13} \mathrm{C} \mathrm{NMR}(75 \mathrm{MHz}$, DMSO-d $\left._{6}\right) \delta 165.82,150.97,150.16,135.49,134.31,133.08,131.88,131.08,129.07,127.71,126.10$, $124.72,122.27,121.73(2 \mathrm{C}), 119.45(2 \mathrm{C}), 112.36,38.95 ; \mathrm{m} / \mathrm{z}(\mathrm{ESI}+) 499[\mathrm{M}]^{+} ; \mathrm{t}_{\mathrm{R}}=12.86 \mathrm{~min}$.

5-(3,4-Dichlorophenyl)-2-(3-(4-(phenylsulfonamido)phenyl)ureido)thiophene-3-carboxylic acid (19)

Yield 88\%; reddish solid; ${ }^{1} \mathrm{H}$ NMR (500 MHz, DMSO-d ${ }_{6}$ ) $\delta 13.04$ (br s, 1H), 10.56 (br s, 1H), 10.29 (br s, 1H), 10.09 (br s, 1H), $7.88(\mathrm{~d}, J=2.2 \mathrm{~Hz}, 1 \mathrm{H}), 7.72(\mathrm{~m}, 2 \mathrm{H}), 7.62(\mathrm{~s}, 1 \mathrm{H}), 7.60(\mathrm{~m}, 2 \mathrm{H}), 7.55$ $(\mathrm{m}, 3 \mathrm{H}), 7.36(\mathrm{~d}, J=9.1 \mathrm{~Hz}, 2 \mathrm{H}), 7.03(\mathrm{~d}, J=9.1 \mathrm{~Hz}, 2 \mathrm{H}) ;{ }^{13} \mathrm{C}$ NMR $(126 \mathrm{MHz}$, DMSO-d 6 ) $\delta 165.76$, $150.87,150.08,139.46,135.56,134.28,132.77,132.27,131.85,131.07,129.16(2 \mathrm{C}), 129.06,127.69$, $126.63(2 \mathrm{C}), 126.10,124.70,122.26,121.88(2 \mathrm{C}), 119.20(2 \mathrm{C}), 112.33 ; \mathrm{m} / \mathrm{z}(\mathrm{ESI}+) 561[\mathrm{M}]^{+} ; \mathrm{t}_{\mathrm{R}}=$ $17.26 \mathrm{~min}$

\section{5-(3,4-Dichlorophenyl)-2-(3-(4-((N,N-dimethylsulfamoyl)amino)phenyl)ureido)thiophene-3-} carboxylic acid (20)

Yield 79\%; beige solid; ${ }^{1} \mathrm{H}$ NMR (500 MHz, DMSO-d 6 ) $\delta 13.06$ (br s, 1H), 10.59 (br s, 1H), 10.31 (br s, 1H), $9.72($ br s, 1H), $7.89(\mathrm{~d}, J=2.2 \mathrm{~Hz}, 1 \mathrm{H}), 7.63(\mathrm{~s}, 1 \mathrm{H}), 7.61(\mathrm{~d}, J=8.2 \mathrm{~Hz}, 1 \mathrm{H}), 7.58(\mathrm{dd}, J=$ 8.2, $2.2 \mathrm{~Hz}, 1 \mathrm{H}), 7.44(\mathrm{~d}, J=9.1 \mathrm{~Hz}, 2 \mathrm{H}), 7.18(\mathrm{~d}, J=9.1 \mathrm{~Hz}, 2 \mathrm{H}), 2.69(\mathrm{~s}, 6 \mathrm{H}) ;{ }^{13} \mathrm{C} \mathrm{NMR}(126 \mathrm{MHz}$, DMSO-d $\left._{6}\right) \delta 165.78,150.95,150.18,134.78,134.31,133.45,131.85,131.07,129.05,127.66,126.10$, 124.70, 122.24, $120.95(2 \mathrm{C}), 119.32(2 \mathrm{C}), 112.27,37.75(2 \mathrm{C}) ; \mathrm{m} / \mathrm{z}(\mathrm{ESI}+) 529[\mathrm{M}+\mathrm{H}]^{+} ; \mathrm{t}_{\mathrm{R}}=17.20$ $\min$. 
Experimental procedures for the synthesis of all other target compounds and necessary precursors together with their characterization and NMR spectra are described in details in the Supporting Information.

Computational Chemistry All computational work was performed using Molecular Operating Environment (MOE) version 2015.10, Chemical Computing Group Inc., 1010 Sherbrooke St. West, Suite 910, Montreal, Quebec, H3A 2R7, Canada.

Similarity Analysis A database containing compounds 2 and $\mathbf{4}$ was created and the fingerprint piDAPH4 (pi-donor-acceptor-polar-hydrophobe-4 point pharmacophore) was calculated for both entries. Compound 4 was selected as a reference structure and sent to MOE window. In the database viewer window, similarity search was performed by setting the fingerprint system to piDAPH4, and using the similarity metric Tanimoto coefficient $\left(\mathrm{T}_{\mathrm{C}}\right)$ to measure similarity between molecules. $\mathrm{T}_{\mathrm{C}}$ values range from 0 (no similarity) to 1 (complete similarity).

Preparation of Ligands and Protein Structure for Docking In the database viewer window, compounds 11 and $\mathbf{1 8}$ were selected and washed via compute | molecule | wash command. Deprotonation of strong acids and protonation of strong bases options were checked in the wash panel. X-ray crystal structure of the HIV-1 RT in complex with NVP (PDB code 1VRT) ${ }^{14}$ was used to perform the molecular docking study. Potential was setup to Amber10:EHT for force field and R-field for solvation. Addition of hydrogen atoms and removal of water molecules were performed via LigX module.

Ligand-Receptor Docking Using the induced fit docking protocol, the binding site was set to dummy atoms which were identified by the site finder mode, and the amino acid residues were chosen where nevirapine binds in the RT allosteric binding site. Docking placement was triangle matcher with rotate bonds option. The $1^{\text {st }}$ rescoring was ASE with force field refinement, and the $2^{\text {nd }}$ rescoring was alpha HB.

QSAR Analysis A database containing compounds 11-20 was created, and each structure was subjected to energy minimization up to a gradient $0.01 \mathrm{kcal} / \mathrm{mol} / \AA ̊ \AA$ using the MMFF94x force field and distance solvation model. In the database viewer window, molecular descriptors were calculated for all 
entries via activating the compute panel, choosing descriptors calculate option (Table S1). The QSAR model was computed using partial least squares (PLS) method.

Binding Measurements were performed at $20{ }^{\circ} \mathrm{C}$ using a Fluoromax 4 spectrofluorometer (JobinYvon Horiba) by monitoring the increase of FRET efficiency, $\mathrm{E}_{\mathrm{FRET}}$, associated to the formation of the complex between Alexa488-labeled RT and TAMRA-labeled p/t duplexes,. The FRET efficiency, calculated by $E_{F R E T}=1-I_{D A} / I_{D}$ (where $I_{D}$ and $I_{D A}$ are the intensities of the Alexa 488 donor in the absence and in the presence of the TAMRA acceptor, respectively), was then plotted as a function of the total concentration of the labeled oligonucleotide (ODN) and fitted with a rewritten Scatchard equation considering a model with a single binding site

$$
E_{F R E T}=E_{F}\left\{\frac{K_{d}+M_{t o t}+L_{t o t}-\sqrt{\left[K_{d}+M_{t o t}+L_{t o t}\right]^{2}-4 M_{t o t} L_{t o t}}}{2 K_{d} L_{t o t}}\right\}
$$

where $E_{F}$ corresponds to the FRET efficiency at saturation, $L_{t o t}$ and $M_{t o t}$ are respectively the concentration of RT and p/t duplex and $K_{d}$ is the dissociation constant. Fit parameters were recovered from non-linear fits of eq 3 to the experimental datasets using a non-linear least-squares method and the Levenberg-Marquardt algorithm in the Origin 8 software.

RT Inhibitory Activity of Compounds was determined as described previously. ${ }^{24}$ All measurements were carried out using a 23-mer (5'- CAG CAG TAC AAA TGG CAG TAT TC) DNA-primer labeled at the T19 position with Cyanine 5 (Cy5), annealed to a 63-mer (3'-TGT CGT CAT GTT TAC CGT CAT AAG TAG GTG TTA CTA GTC CGA TTT CCC CTA GTC CGA CCC ATG)-template labeled at the T2 position with TAMRA. Both TAMRA and Cy5 were covalently attached via a C6 amino link to their respective T residues in the primer and the template. Primer and template ODN were annealed by heating equimolar amounts in buffer at $90{ }^{\circ} \mathrm{C}$ for $2 \mathrm{~min}$, followed by cooling to room temperature over several hours. All measurements were performed at $20{ }^{\circ} \mathrm{C}$ using a Fluoromax 4 spectrofluorometer (Jobin-Yvon Horiba) or a stopped-flow apparatus (SF3, Biologics). The FRET donor, TAMRA, was excited at $540 \mathrm{~nm}$, and its emission was recorded at $580 \mathrm{~nm}$. Nucleotide incorporation kinetics was triggered by addition of dNTPs in excess to a pre-incubated mixture of 
HIV-RT and p/t duplexes at equimolar concentrations. The annealing kinetic traces were adequately fitted using

$$
I(t)=I_{F}-\left(I_{F}-I_{0}\right)\left(a e^{\left(-k_{o b s 1}(t-t 0)\right)}-(1-a) e^{\left(-k_{o b s 2}(t-t 0)\right)}\right)
$$

where $t 0$ is the dead time, $k_{o b s l, 2}$ are the observed kinetic rate constants, $a$ is the amplitude of the fast component, and $I_{0}$ and $I_{F}$ are the fluorescence intensities before dNTPs addition and at completion of the reaction, respectively. The $I_{0}$ value was obtained from the steady-state fluorescence spectrum of the doubly labeled p/t duplex in the presence of RT and was thus fixed. All fitting procedures were carried out with Origin ${ }^{\mathrm{TM}} 8.6$ software using nonlinear, least-square methods and the LevenbergMarquardt algorithm.

HeLa Infectivity and Cytotoxicity Assay The infectivity assay was based on infection of Hela cells by a third-generation of pseudoparticles ${ }^{38}$ mimicking the early steps of the HIV-1 virus cycle. The pseudoparticles contain Gag, Gag-pol, RRE and Vesicular Stomatitis Virus (VSV)-G proteins and a RNA encoding reporter gene for luciferase. The luciferase sequence is incorporated in the host genome during infection by pseudoparticles which give the possibility to quantify infection. A total of $5 \times 10^{3} \mathrm{HeLa}$ cells/well were seeded in 96 wells plate $24 \mathrm{~h}$ prior to infection in Dulbecco's Modified Eagle Medium (Life Technologies) (DMEM) complemented with $10 \%$ fetal bovine serum, penicillin (100 UI/mL), and streptomycin $(100 \mu \mathrm{g} / \mathrm{mL})$ and incubated in a $5 \% \mathrm{CO}_{2}$ incubator. After medium removal, $50 \mu \mathrm{L}$ of two times concentrated solutions of compounds were added 30 min before adding $50 \mu \mathrm{L}$ of pseudoparticles, which can infect $50 \%$ of cells in presence of polybrene $(8 \mu \mathrm{g} / \mathrm{mL})$. Cells were washed, $24 \mathrm{~h}$ after infection, one time by PBS and lysed with Passive Lysis Buffer (Promega) supplemented with $0.5 \%$ Triton $\mathrm{X}-100$ for 30 min under constant shaking. Luciferase activity was measured for $10 \mathrm{~s}$ in a luminometer (Tristar 2 Multimode reader LB 942, Berthold) after injection of $50 \mu \mathrm{L}$ of luciferine reagent $(25 \mathrm{mM}$ Tricine Buffer $\mathrm{pH}=7.8,0.5 \mathrm{mM}$ EDTA pH 7.9, $5 \mathrm{mM} \mathrm{MgSO} 4,5$ mM DTT, $0.5 \mathrm{mM}$ ATP, $1.65 \mathrm{mM}$ D-luciferin sodium salt and $0.325 \mathrm{mM}$ Coenzyme A Sodium Salt hydrate).

For each compound, we used as a control, cells incubated with DMEM containing the same percentage of DMSO (maximum $0.5 \% \mathrm{v} / \mathrm{v}$ ) as the solutions with the tested molecules. For each tested 
molecule and concentration, we calculated the percentage of inhibition (\%inh) with the following equation

$\%$ inh or $\%$ cyt $=\frac{(\text { Control value })-(\text { Sample value })}{(\text { Control value })} \times 100$

Each concentration of tested compound was tested in sextuplicate. To determine the $\mathrm{IC}_{50}$ values, we plotted the percentage of inhibition against the inhibitor concentration $(I)$ and fitted it with a modified version of the dose-response effect equation

$$
y=\frac{A_{1}+\left(A_{2}-A_{1}\right)}{1+10^{\left.\left(\log \left(I_{50}\right)-\log (I)\right)^{*} p\right)}}
$$

where, $A_{1}$ and $A_{2}$ represent the percentage of inhibition in the absence $(0 \%)$ and in saturating concentrations $(100 \%)$ of inhibitor, respectively. $I_{50}$ represents the half maximal inhibitory concentration and $p$ denotes hill coefficient.

Cytotoxicity of compounds was quantified by the MTT assay (3-(4,5-dimethylthiazol-2-yl)-2,5diphenyl tetrazolium bromide). ${ }^{41}$ Another plate was prepared in the same conditions as for the infectivity assay. $24 \mathrm{~h}$ after infection, medium was replaced by $110 \mu \mathrm{L}$ of a mix containing $100 \mu \mathrm{L}$ of DMEM and $10 \mu \mathrm{L}$ of $12 \mathrm{mM}$ MTT solution in PBS and cells were incubated during $4 \mathrm{~h}$. In order to dissolve the insoluble purple formazan reduced by living cells, $85 \mu \mathrm{L}$ of the mix was replaced by 50 $\mu \mathrm{L}$ of DMSO and gently shaken for $10 \mathrm{~min}$. The absorbance was then measured at $540 \mathrm{~nm}$ in a spectrophotometer (Safas Monaco) and converted in percentage of cytotoxicity (\% cyt), in reference to the control (DMEM + DMSO).

Antiretroviral Assay against HIV-1 WT and NNRTIs-Resistant Strains The WT virus and the NNRTIs-resistant strains were obtained through the NIH AIDS Reagent Program (ARP, www.aidsreagent.org) and have been already characterized by the Phenosense Assay (Monogram Biosciences), considered as the reference assay for phenotypic investigation of HIV drug resistance due to its large application in clinical trials. The infectious clones were firstly transfected in 293LX cells and then expanded in MT-2 cells. The antiretroviral assay was determined in a TZM-bl cell line based phenotypic assay. TZM-bl cells are characterized by the presence of the luciferase and $\beta$ galactosidase reporter genes integrated in the cell genome under control of the HIV-1 LTR promoter. 
Expression of the reporter genes is regulated by the viral Tat protein, which is produced following transcription of the integrated provirus. TZM-bl cells were seeded at a concentration of 30,000 cells/well in a 96-well plate using DMEM medium without fetal bovine serum (FBS) and infected with the viruses in the presence of $20,10,5$ and $1 \mu \mathrm{M}$ of each compound. After 48 hours, cells were lysed by adding $40 \mu \mathrm{L}$ of Glo Lysis Buffer (Promega) to each well for 5 minutes, then $40 \mu \mathrm{L}$ of Bright-Glo Luciferase Reagent (Promega) were added to each well for counting relative luminescence units (RLU) using the Glo-Max Multi Detection System (Promega). RLU values from each well were elaborated using the GraphPad v5.0 software to calculate the $\mathrm{IC}_{50}$ of each compound.

RNAP Inhibition, Antibacterial Activity and Cytotoxicity Transcription inhibition assay, determination of IC $_{50}$ values, minimal inhibitory concentrations (MICs) and cytotoxicity in HEK 293 cells were performed as described previously. ${ }^{22}$

\section{ASSOCIATED CONTENT}

\section{Supporting Information}

This material is available free of charge via the Internet at http://pubs.acs.org.

Experimental procedures and analytical data for all other compounds; Substituent constants and molecular descriptors of compounds 11-20; Binding and mechanistic studies of the compounds; ${ }^{1} \mathrm{H}$ and ${ }^{13} \mathrm{C}$ NMR spectra (PDF)

Molecular formula strings (CSV)

\section{AUTHOR INFORMATION}

\section{Corresponding Author}

*E-mail: rolf.hartmann@helmholtz-hzi.de, Phone: +(49) 68130270300.

\section{ACKNOWLEDGMENTS}

The authors thank Jeannine Jung for technical assistance. Walid A. M. Elgaher gratefully acknowledges a scholarship from the German Academic Exchange Service (DAAD). Kamal K. Sharma, Francesco Saladini, Manuel Pires and part of this work were supported by the European Project THINPAD "Targeting the HIV-1 Nucleocapsid Protein to fight Antiretroviral Drug Resistance" [FP7-Grant Agreement 601969 to Y.M.]. 


\section{ABRREVIATIONS USED}

ART, antiretroviral therapy; AZT-TP, azidothymidine triphosphate; BTC, bis(trichloromethyl) carbonate; DMEM, Dulbecco's modified Eagle's medium; dNTPs, deoxyribonucleotides; EFV, efavirenz; ETR, etravirine; FBS, fetal bovine serum; HAART, highly active antiretroviral therapy; LLE, ligand-lipophilicity efficiency; MoA, mode of action; Mtb, Mycobacterium tuberculosis; MTT, 3-(4,5-dimethylthiazol-2-yl)-2,5-diphenyl tetrazolium bromide; NVP, nevirapine; ODN, oligonucleotide; piDAPH4, pi-donor-acceptor-polar-hydrophobe-4 point pharmacophore; p/t, primer/template; RLU, relative luminescence units; RNAP, RNA polymerase; RPV, rilpivirine; RT, reverse transcriptase; TAMRA, carboxytetramethylrhodamine; $\mathrm{T}_{\mathrm{C}}$, Tanimoto coefficient; TEA, triethylamine.

\section{REFERENCES}

(1) WHO. HIV/AIDS, Fact sheet N³60, 2015. http://www.who.int/mediacentre/factsheets/fs360/en/.

(2) Bonnet, M. M. B.; Pinoges, L. L. P.; Varaine, F. F. V.; Oberhauser, B. B. O.; O'Brien, D. D. O.; Kebede, Y. Y. K.; Hewison, C. C. H.; Zachariah, R. R. Z.; Ferradini, L. L. F. Tuberculosis after HAART Initiation in HIV-Positive Patients from Five Countries with a High Tuberculosis Burden. AIDS (London, U.K.) 2006, 20, 1275-1279.

(3) Mathews, W. C.; Caperna, J. C.; Barber, R. E.; Torriani, F. J.; Miller, L. G.; May, S.; McCutchan, J. A. Incidence of and Risk Factors for Clinically Significant Methicillin-Resistant Staphylococcus aureus Infection in a Cohort of HIV-Infected Adults. J. Acquir. Immune Defic. Syndr. 2005, 40, 155160.

(4) Hidron, A. I.; Kempker, R.; Moanna, A.; Rimland, D. Methicillin-Resistant Staphylococcus aureus in HIV-Infected Patients. Infect. Drug Resist. 2010, 3, 73-86.

(5) Crum-Cianflone, N. F.; Burgi, A. A.; Hale, B. R. Increasing Rates of Community-Acquired Methicillin-Resistant Staphylococcus aureus Infections among HIV-Infected Persons. Int. J. STD AIDS 2007, 18, 521-526.

(6) Martin, J. N.; Rose, D. A.; Hadley, W. K.; Perdreau-Remington, F.; Lam, P. K.; Gerberding, J. L. Emergence of Trimethoprim-Sulfamethoxazole Resistance in the AIDS Era. J. Infect. Dis. 1999, 180, 1809-1818. 
(7) Diep, B. A.; Chambers, H. F.; Graber, C. J.; Szumowski, J. D.; Miller, L. G.; Han, L. L.; Chen, J. H.; Lin, F.; Lin, J.; Phan, T. H.; Carleton, H. A.; McDougal, L. K.; Tenover, F. C.; Cohen, D. E.; Mayer, K. H.; Sensabaugh, G. F.; Perdreau-Remington, F. Emergence of Multidrug-Resistant, Community-Associated, Methicillin-Resistant Staphylococcus aureus Clone USA300 in Men Who Have Sex with Men. Ann. Intern. Med. 2008, 148, 249-257.

(8) Mansky, L. M. HIV Mutagenesis and the Evolution of Antiretroviral Drug Resistance. Drug Resist. Update. 2002, 5, 219-223.

(9) Asahchop, E. L.; Wainberg, M. A.; Sloan, R. D.; Tremblay, C. L. Antiviral Drug Resistance and the Need for Development of New HIV-1 Reverse Transcriptase Inhibitors. Antimicrob. Agents Chemother. 2012, 56, 5000-5008.

(10) Tang, M. W.; Shafer, R. W. HIV-1 Antiretroviral Resistance: Scientific Principles and Clinical Applications. Drugs 2012, 72, e1-e25.

(11) Dejesus, E.; Young, B.; Morales-Ramirez, J. O.; Sloan, L.; Ward, D. J.; Flaherty, J. F.; Ebrahimi, R.; Maa, J.-F.; Reilly, K.; Ecker, J.; McColl, D.; Seekins, D.; Farajallah, A. Simplification of Antiretroviral Therapy to a Single-Tablet Regimen Consisting of Efavirenz, Emtricitabine, and Tenofovir Disoproxil Fumarate versus Unmodified Antiretroviral Therapy in Virologically Suppressed HIV-1-Infected Patients. J. Acquir. Immune Defic. Syndr. 2009, 51, 163-174.

(12) Piscitelli, S. C.; Gallicano, K. D. Interactions among Drugs for HIV and Opportunistic Infections. N. Engl. J. Med. 2001, 344, 984-996.

(13) Krentz, H. B.; Gill, M. J. Increased Costs of HIV Care Associated with Aging in an HIVInfected Population. HIV Med. 2015, 16, 38-47.

(14) Ren, J.; Esnouf, R.; Garman, E.; Somers, D.; Ross, C.; Kirby, I.; Keeling, J.; Darby, G.; Jones, Y.; Stuart, D.; Stammers, D. High Resolution Structures of HIV-1 RT from Four RT-Inhibitor Complexes. Nat. Struct. Mol. Biol. 1995, 2, 293-302.

(15) Ding, J.; Das, K.; Moereels, H.; Koymans, L.; Andries, K.; Janssen, P. A.; Hughes, S. H.; Arnold, E. Structure of HIV-1 RT/TIBO R 86183 Complex Reveals Similarity in the Binding of Diverse Nonnucleoside Inhibitors. Nat. Struct. Mol. Biol. 1995, 2, 407-415. 
(16) Engelman, A.; Cherepanov, P. The Structural Biology of HIV-1: Mechanistic and Therapeutic Insights. Nat. Rev. Microbiol. 2012, 10, 279-290.

(17) Vassylyev, D. G.; Sekine, S.-i.; Laptenko, O.; Lee, J.; Vassylyeva, M. N.; Borukhov, S.; Yokoyama, S. Crystal Structure of a Bacterial RNA Polymerase Holoenzyme at 2.6 A Resolution. Nature 2002, 417, 712-719.

(18) Kotler, M.; Becker, Y. Rifampicin and Distamycin A as Inhibitors of Rous Sarcoma Virus Reverse Transcriptase. Nat. New Biol. 1971, 234, 212-214.

(19) Szilvay, A. M.; Stern, B.; Blichenberg, A.; Helland, D. E. Structural and Functional Similarities between HIV-1 Reverse Transcriptase and the Escherichia coli RNA Polymerase $\beta^{\prime}$ Subunit. FEBS Lett. 2000, 484, 43-47.

(20) Mukhopadhyay, J.; Das, K.; Ismail, S.; Koppstein, D.; Jang, M.; Hudson, B.; Sarafianos, S.; Tuske, S.; Patel, J.; Jansen, R.; Irschik, H.; Arnold, E.; Ebright, R. H. The RNA Polymerase "Switch Region" is a Target for Inhibitors. Cell 2008, 135, 295-307.

(21) Sahner, J. H.; Groh, M.; Negri, M.; Haupenthal, J.; Hartmann, R. W. Novel Small Molecule Inhibitors Targeting the "Switch Region" of Bacterial RNAP: Structure-Based Optimization of a Virtual Screening Hit. Eur. J. Med. Chem. 2013, 65, 223-231.

(22) Elgaher, W. A. M.; Fruth, M.; Groh, M.; Haupenthal, J.; Hartmann, R. W. Expanding the Scaffold for Bacterial RNA Polymerase Inhibitors: Design, Synthesis and Structure-Activity Relationships of Ureido-Heterocyclic-Carboxylic Acids. RSC Adv. 2014, 4, 2177-2194.

(23) Fruth, M.; Plaza, A.; Hinsberger, S.; Sahner, J. H.; Haupenthal, J.; Bischoff, M.; Jansen, R.; Müller, R.; Hartmann, R. W. Binding Mode Characterization of Novel RNA Polymerase Inhibitors Using a Combined Biochemical and NMR Approach. ACS Chem. Biol. 2014, 9, 2656-2663.

(24) Sharma, K. K.; Przybilla, F.; Restle, T.; Godet, J.; Mély, Y. FRET-Based Assay to Screen Inhibitors of HIV-1 Reverse Transcriptase and Nucleocapsid Protein. Nucleic Acids Res. [Online early access]. DOI: 10.1093/nar/gkv1532. Published Online: January 13, 2016.

(25) Srivastava, A.; Talaue, M.; Liu, S.; Degen, D.; Ebright, R. Y.; Sineva, E.; Chakraborty, A.; Druzhinin, S. Y.; Chatterjee, S.; Mukhopadhyay, J.; Ebright, Y. W.; Zozula, A.; Shen, J.; Sengupta, S.; Niedfeldt, R. R.; Xin, C.; Kaneko, T.; Irschik, H.; Jansen, R.; Donadio, S.; Connell, N.; Ebright, R. H. 
New Target for Inhibition of Bacterial RNA Polymerase: 'Switch Region'. Curr. Opin. Microbiol. 2011, $14,532-543$.

(26) Rodgers, D. W.; Gamblin, S. J.; Harris, B. A.; Ray, S.; Culp, J. S.; Hellmig, B.; Woolf, D. J.; Debouck, C.; Harrison, S. C. The Structure of Unliganded Reverse Transcriptase from the Human Immunodeficiency Virus Type 1. Proc. Natl. Acad. Sci. U.S.A. 1995, 92, 1222-1226.

(27) Esnouf, R.; Ren, J.; Ross, C.; Jones, Y.; Stammers, D.; Stuart, D. Mechanism of Inhibition of HIV-1 Reverse Transcriptase by Non-Nucleoside Inhibitors. Nat. Struct. Mol. Biol. 1995, 2, 303-308.

(28) Mason, J. S.; Morize, I.; Menard, P. R.; Cheney, D. L.; Hulme, C.; Labaudiniere, R. F. New 4Point Pharmacophore Method for Molecular Similarity and Diversity Applications: Overview of the Method and Applications, Including a Novel Approach to the Design of Combinatorial Libraries Containing Privileged Substructures. J. Med. Chem. 1999, 42, 3251-3264.

(29) Leeson, P. D.; Springthorpe, B. The Influence of Drug-Like Concepts on Decision-Making in Medicinal Chemistry. Nat. Rev. Drug Discov. 2007, 6, 881-890.

(30) Domaoal, R. A.; Demeter, L. M. Structural and Biochemical Effects of Human Immunodeficiency Virus Mutants Resistant to Non-Nucleoside Reverse Transcriptase Inhibitors. Int. J. Biochem. Cell Biol. 2004, 36, 1735-1751.

(31) Pelemans, H.; Esnouf, R.; Clercq, E. de; Balzarini, J. Mutational Analysis of Trp-229 of Human Immunodeficiency Virus Type 1 Reverse Transcriptase (RT) Identifies This Amino Acid Residue as a Prime Target for the Rational Design of New Non-Nucleoside RT Inhibitors. Mol. Pharmacol. 2000, 57, 954-960.

(32) Wohrl, B. M.; Krebs, R.; Thrall, S. H.; Le Grice, S. F. J.; Scheidig, A. J.; Goody, R. S. Kinetic Analysis of Four HIV-1 Reverse Transcriptase Enzymes Mutated in the Primer Grip Region of p66. Implications for DNA Synthesis and Dimerization. J. Biol. Chem. 1997, 272, 17581-17587.

(33) Smerdon, S. J.; Jäger, J.; Wang, J.; Kohlstaedt, L. A.; Chirino, A. J.; Friedman, J. M.; Rice, P. A.; Steitz, T. A. Structure of the Binding Site for Nonnucleoside Inhibitors of the Reverse Transcriptase of Human Immunodeficiency Virus Type 1. Proc. Natl. Acad. Sci. U.S.A. 1994, 91, 3911-3915. 
(34) Sharma, K. K.; Przybilla, F.; Restle, T.; Boudier, C.; Godet, J.; Mély, Y. Reverse Transcriptase in Action: FRET-Based Assay for Monitoring Flipping and Polymerase Activity in Real Time. Anal. Chem. 2015, 87, 7690-7697.

(35) Grohmann, D.; Godet, J.; Mély, Y.; Darlix, J.-L.; Restle, T. HIV-1 Nucleocapsid Traps Reverse Transcriptase on Nucleic Acid Substrates. Biochemistry 2008, 47, 12230-12240.

(36) Spence, R.; Kati, W.; Anderson, K.; Johnson, K. Mechanism of Inhibition of HIV-1 Reverse Transcriptase by Nonnucleoside Inhibitors. Science 1995, 267, 988-993.

(37) Kohlstaedt, L. A.; Wang, J.; Friedman, J. M.; Rice, P. A.; Steitz, T. A. Crystal Structure at 3.5 A Resolution of HIV-1 Reverse Transcriptase Complexed with an Inhibitor. Science 1992, 256, 17831790.

(38) Dull, T.; Zufferey, R.; Kelly, M.; Mandel, R. J.; Nguyen, M.; Trono, D.; Naldini, L. A ThirdGeneration Lentivirus Vector with a Conditional Packaging System. J. Virol. 1998, 72, 8463-8471.

(39) Balamane, M.; Varghese, V.; Melikian, G. L.; Fessel, W. J.; Katzenstein, D. A.; Shafer, R. W. Panel of Prototypical Recombinant Infectious Molecular Clones Resistant to Nevirapine, Efavirenz, Etravirine, and Rilpivirine. Antimicrob. Agents Chemother. 2012, 56, 4522-4524.

(40) Hsiou, Y.; Ding, J.; Das, K.; Clark, A. D.; Boyer, P. L.; Lewi, P.; Janssen, P. A.; Kleim, J. P.; Rösner, M.; Hughes, S. H.; Arnold, E. The Lys103Asn Mutation of HIV-1 RT: a Novel Mechanism of Drug Resistance. J. Mol. Biol. 2001, 309, 437-445.

(41) Mosmann, T. Rapid Colorimetric Assay for Cellular Growth and Survival: Application to Proliferation and Cytotoxicity Assays. J. Immunol. Methods 1983, 65, 55-63. 